\title{
RADIOLYTIC GAS PRODUCTION FROM CONCRETE CONTAINING SAVANNAH RIVER PLANT WASTE
}

by

N. E. Bibler

M. L. Hyder, Research Manager

Separations Chemistry Division

Publication Date: January 1978

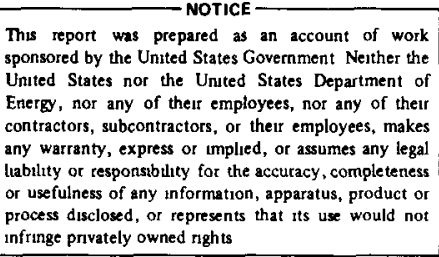

sponsored by the United States Government Netther the

United States nor the Unuted States Department of

Energy, nor any of their employees, nor any of their

any warranty, express or umplied, or assumes any lega

lability or responsibulity for the acculacy, completerness

or usefulness of any information, apparatus, product or

infringe privately owned nghts

E. I. du PONT de NEMOURS AND COMPANY SAVANNAH RIVER LABORATORY

AIKEN, SOUTH CAROLINA 29801

PREPARED FOR THE U.S. DEPARTMENT OF ENERGY UNDER CONTRACT AT(07 2) 1 


\section{DISCLAIMER}

This report was prepared as an account of work sponsored by an agency of the United States Government. Neither the United States Government nor any agency Thereof, nor any of their employees, makes any warranty, express or implied, or assumes any legal liability or responsibility for the accuracy, completeness, or usefulness of any information, apparatus, product, or process disclosed, or represents that its use would not infringe privately owned rights. Reference herein to any specific commercial product, process, or service by trade name, trademark, manufacturer, or otherwise does not necessarily constitute or imply its endorsement, recommendation, or favoring by the United States Government or any agency thereof. The views and opinions of authors expressed herein do not necessarily state or reflect those of the United States Government or any agency thereof. 


\section{DISCLAIMER}

Portions of this document may be illegible in electronic image products. Images are produced from the best available original document. 
To determine the extent of gas production from radiolysis of concrete containing radioactive Savannah River Plant waste, samples of concrete and simulated waste were irradiated by ${ }^{6} \mathrm{Co}$ gamma rays and ${ }^{244} \mathrm{Cm}$ alpha particles. Gamma radiolysis simulated radiolysis by beta particles from fission products in the waste. Alpha radiolysis indicated the effect of alpha particles from transuranic isotopes in the waste.

With gamma radiolysis, hydrogen was the only significant product; hydrogen reached a steady-state pressure that increased with increasing radiation intensity. Hydrogen was produced faster, and a higher steady-state pressure resulted when an organic set retarder was present. Oxygen that was sealed with the wastes was depleted. Gamma radiolysis also produced nitrous oxide gas when nitrate or nitrite was present in the concrete. With alpha radiolysis, hydrogen and oxygen were produced. Hydrogen did not reach a steady-state pressure at <140 psi.

From these results, estimates of pressure in conceptual containers (cylinders 2 feet ID by 10 feet tal1, 90\% full) of SRP waste concrete were made. During the first 300 years of storage when radiolysis will mainly be from beta-gamma radiation (from ${ }^{137} \mathrm{Cs}$ and ${ }^{90} \mathrm{Sr}$ ), hydrogen will reach a steady-state pressure of 8 to $28 \mathrm{psi}$, and oxygen will be partially consumed. These predictions were confirmed by measurement of gas produced over a short time in a container of concrete and actual SRP waste. The tests with simulated waste also indicated that nitrous oxide may form, but because of the low nitrate or nitrite content of the waste, the maximum pressure of nitrous oxide after 300 years will be $<60 \mathrm{psi}$. After decay of these fission products, alpha radiolysis from ${ }^{238} \mathrm{Pu}$ and ${ }^{239} \mathrm{Pu}$ will predominate; the hydrogen and oxygen pressures will increase to $>200$ psi. 
Introduction 7

Composition of Simulated Wastes 9

Gamma Radiolysis of Concrete Containing $\mathrm{Fe}_{2} \mathrm{O}_{3}$ or $\mathrm{MnO}_{2} 9$

High and Low Dose Rate Tests in Absence of Added $\mathrm{NO}_{3}{ }^{-}$or $\mathrm{NO}_{2}{ }^{-} 9$

Low Dose Rate Tests in Presence of Added $\mathrm{NO}_{3}{ }^{-}$or $\mathrm{NO}_{2}{ }^{-}$Ions 13

Gamma Radiolysis of Concrete Containing SRP Simulated Wastes 17

Gamma Radiolysis of Concrete Containing SRP Simulated Waste and an Organic Set Retarder 19

Experimental Procedures for Gamma Radiolysis Tests 21

Alpha Radiolysis of Concrete Containing SRP Simulated Wastes 22

Radiation Doses to Concrete from SRP Waste During Long-Term Storage 25

Measured Pressurization in Containers of Concrete and SRP Waste 28

Calculated Pressurization in Containers of Concrete and SRP Waste During Long-Term Storage 30

$\mathrm{H}_{2}$ and $\mathrm{O}_{2}$ Production 30

$\mathrm{N}_{2} \mathrm{O}$ Production 33

He Production 34

Mechanism for Radiolytic Gas Production 34

References $\quad 38$ 


\section{LIST OF FIGURES}

1 Conceptual Waste Solidification Process 7

2 Pressure from Gamma Radiolysis at $8.9 \times 10^{4} \mathrm{rads} / \mathrm{hr}$ of Concrete Containing $\mathrm{Fe}_{2} \mathrm{O}_{3}$ or $\mathrm{MnO}_{2}$ as Simulated Waste 10

3 Pressure from Gamma Radiolysis at Two Dose Rates of Concrete Containing $\mathrm{Fe}_{2} \mathrm{O}_{3} \quad 11$

4 Pressure from Gamma Radiolysis at $2.8 \times 10^{7} \mathrm{rads} / \mathrm{hr}$ of Concrete Containing $\mathrm{Fe}_{2} \mathrm{O}_{3}$ or $\mathrm{MnO}_{2}$ as Simulated Waste 11

5 Effect of Dose Rate on Steady-State $\mathrm{H}_{2}$ Pressures 12

6 Pressure from Gamma Radiolysis at $8.9 \times 10^{4} \mathrm{rads} / \mathrm{hr}$ of Concrete Containing $\mathrm{Fe}_{2} \mathrm{O}_{3}$ with Sorbed $\mathrm{NO}_{3}{ }^{-}$and $\mathrm{NO}_{2}^{-}$Ions 14

7 Pressure from Gamma Radiolysis at $2.8 \times 10^{7} \mathrm{rads} / \mathrm{hr}$ of Concrete Containing $\mathrm{Fe}_{2} \mathrm{O}_{3}$ with Sorbed $\mathrm{NO}_{3}{ }^{-}$Ions 16

8 Pressure from Gamma Radiolysis at $8.9 \times 10^{4} \mathrm{rads} / \mathrm{hr}$ of Concrete Containing SRP Simulated Wastes 17

9 Pressure from Gamma Radiolysis at $1.4 \times 10^{7} \mathrm{rads} / \mathrm{hr}$ of Concrete Containing SRP Simulated Wastes 18

10 Pressure from Gamma Radiolysis at $8.9 \times 10^{4} \mathrm{rads} / \mathrm{hr}$ of Concrete Containing Fe-Al Simulated Waste and Ascorbic Acid Set Retarder 19

11 Pressure from Gamma Radiolysis at $1.4 \times 10^{7} \mathrm{rads} / \mathrm{hr}$ of Concrete Containing Fe-Al Simulated Waste and Ascorbic Acid Set Retarder 20

12 Pressure from Short-Term Alpha Radiolysis of Concrete Containing SRP Simulated Wastes 23

13 Pressure from Long-Term Alpha Radiolysis of Concrete Containing Fe-Mn Simulated SRP Waste 24 
14 Calculated Dose Rates in Concrete Containing Radioactive SRP Waste 25

15 Calculated Doses in Concrete Containing Radioactive SRP Waste 26

16 Pressure from Concrete Containing Radioactive SRP Waste 28

17 Estimate of Long-Term Pressurization from Concrete Containing Radioactive SRP Waste 31

18 Effect of Bromide Ions on Pressurization from Gamma Radiolysis of Concrete 36

\section{LIST OF TABLES}

1 Data for Gamma Radiolysis of Concrete Containing $\mathrm{Fe}_{2} \mathrm{O}_{3}$ or $\mathrm{MnO}_{2}$ as Simulated Waste 10

2 Effect of Gas Volume and Water-to-Cement Ratio on Steady-State $\mathrm{H}_{2}$ Pressures 13

3 Data for Gamma Radiolysis of Concrete Containing $\mathrm{Fe}_{2} \mathrm{O}_{3}$ with Sorbed $\mathrm{NO}_{3}{ }^{-}$or $\mathrm{NO}_{2}{ }^{-}$Ions 15

4 Data for Gamma Radiolysis of Concrete Containing SRP Simulated Wastes 18

5 Data for Gamma Radiolysis of Concrete Containing Fe-Al Simulated Waste and Ascorbic Acid Set Retarder 20

6 Data for Alpha Radiolysis of Concrete Containing SRP Simulated Wastes 23

7 Principal Isotopes Solidified in SRP Concrete Waste 27

8 Major Components in Washed, Dried Tank 15 Waste 30 



\section{RADIOLYTIC GAS PRODUCTION FROM CONCRETE CONTAINING SAVANNAH RIVER PLANT WASTE}

\section{INTRODUCTION}

Savannah River Laboratory (SRL) is evaluating methods for solidifying and storing Savannah River Plant (SRP) high-level radioactive waste. ${ }^{1-8}$ In one of several options, waste can be solidified as glass or concrete and stored in an onsite facility until it is shipped to a Federal repository. An earlier report ${ }^{1}$ detailed the origins and characteristics of SRP wastes and the criteria for acceptable solid waste forms. One conceptual process based on that study is shown in Figure 1. Another conceptual process being considered is vitrification of the waste.

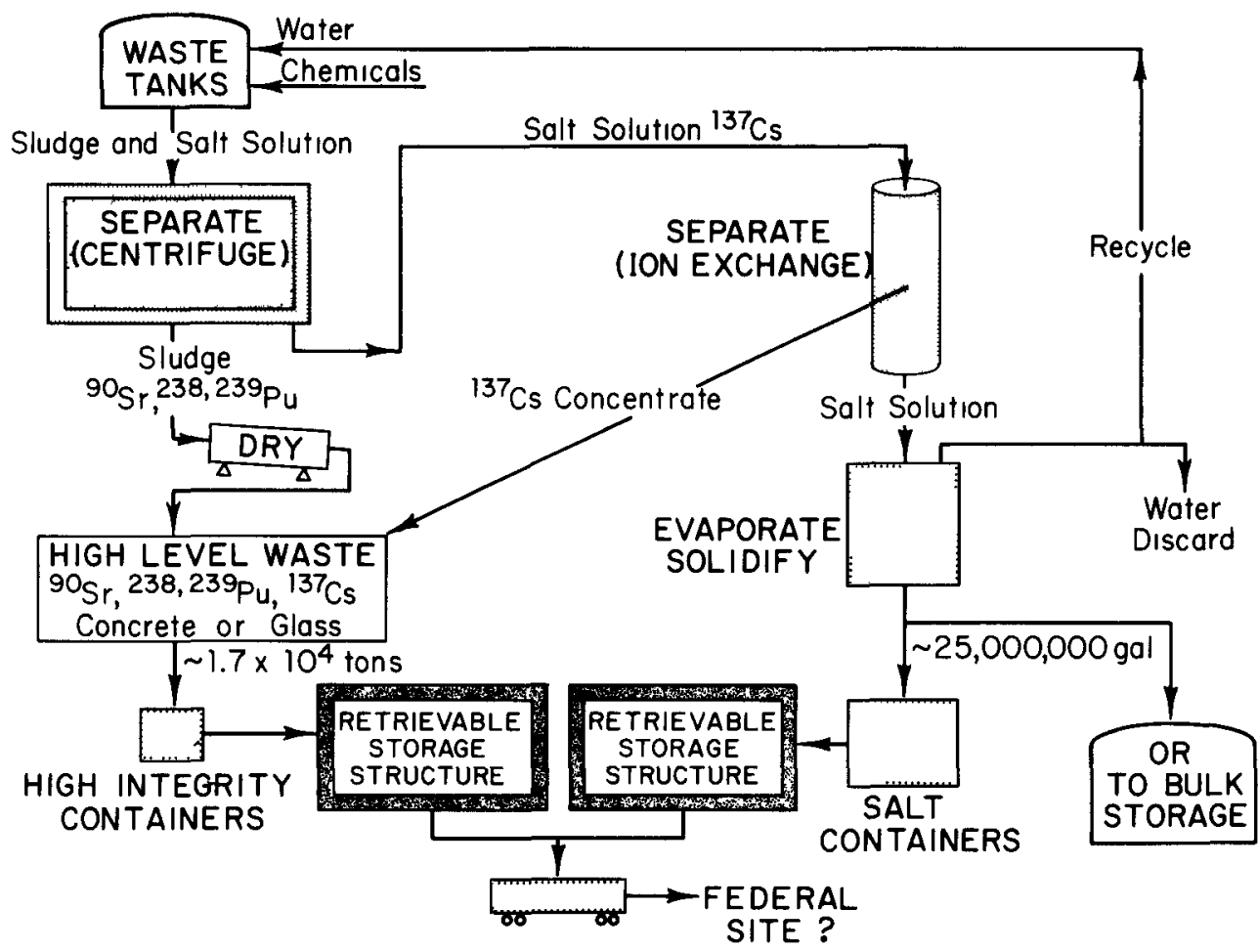

FIGURE 1. Conceptual Waste Solidification Process 
SRP wastes consist of an alkaline salt solution, a solid salt cake (mostly nitrate and nitrite), and an insoluble sludge containing most of the radioactivity and large amounts of iron, aluminum, manganese, uranium, and other elements. Principal sources of radiation are ${ }^{90} \mathrm{Sr},{ }^{137} \mathrm{Cs},{ }^{238} \mathrm{Pu}$, and ${ }^{239} \mathrm{Pu}$. In the conceptual process, sludge is separated from the salt cake and solution, is washed to remove residual nitrate and nitrite ions sorbed from the solution, and is then dried. Soluble ${ }^{137} \mathrm{Cs}$ is removed from the solution by ion exchange $e^{3,4}$ and mixed with the sludge. These materials can then be solidified in a glass or concrete matrix and sealed inside steel containers for long-term storage. If solidified in glass, the dried sludge and ${ }^{137} \mathrm{Cs}$ from ion exchange can be mixed with a glass frit and melted. If solidified in concrete, the ${ }^{137} \mathrm{Cs}$ can be transferred to zeolite and mixed with the dried sludge. This mixture can then be used as aggregate for making concrete.

Glass and concrete as solidification matrices for SRP wastes have been studied extensively at SRL. ${ }^{5-8}$ These forms are attractive for radioactive waste storage because they are compatible with SRP wastes and have high compressive strengths and low leachabilities for ${ }^{90} \mathrm{Sr},{ }^{137} \mathrm{Cs}$, and the transuranic isotopes ${ }^{238} \mathrm{Pu}$ and ${ }^{2}{ }^{9} \mathrm{Pu}$. The effects of gamma and alpha radiation on glass forms have been evaluated. ${ }^{5-8}$ Radiolysis does not produce gaseous products, nor does it affect the leachabilities of overall appearances of the forms. With concrete, only the effects of radiation on compressive strengths and leachabilities have previously been evaluated. ${ }^{5}$ No detrimental effects were detected.

This report presents results of a study to determine if radiolysis of concrete waste during long-term storage will produce significant amounts of gases. Large gas pressures could breach the waste container. In this study, samples of simulated SRP wastes were mixed with a high-alumina cement to make concretes. These samples were then irradiated with ${ }^{60} \mathrm{Co}$ gamma rays or ${ }^{244} \mathrm{Cm}$ alpha particles. Previous study has shown that high-alumina cement is superior for solidification of SRP waste. ${ }^{5}$ Nominal composition (wt \%) of this cement is $\mathrm{Al}_{2} \mathrm{O}_{3}, 41 ; \mathrm{CaO}, 37 ; \mathrm{SiO}_{2}, 9 ; \mathrm{Fe}_{2} \mathrm{O}_{3}, 6$; and MgO, 2 with small amounts of other oxides. Radiolysis with ${ }^{60} \mathrm{Co}$ gamma rays simulated beta radiolysis from the fission products ${ }^{90} \mathrm{Sr}$ and ${ }^{137} \mathrm{Cs}$ in the waste. Radiolysis with ${ }^{244} \mathrm{Cm}$ alpha particles simulated alpha radiolysis by the transuranic isotopes. Samples were irradiated in gas-tight steel containers. Each container had a pressure gage and a sampling valve. During radiolysis, the pressure was monitored; and after radiolysis, the gas was sampled. Its composition was determined by gas chromatography. Results of these tests were used to estimate radiolytic pressurization in containers of concrete and SRP radioactive waste during long-term storage. 


\section{COMPOSITION OF SIMULATED WASTES}

The main components of SRP radioactive wastes are hydrous oxides of $\mathrm{Al}, \mathrm{Fe}$, and $\mathrm{Mn}$. For initial radiolysis tests, reagentgrade $\mathrm{Fe}_{2} \mathrm{O}_{3}$ or $\mathrm{MnO}_{2}$ was used as simulated waste. $\mathrm{Al}_{2} \mathrm{O}_{3}$ was not tested individually because it was always present as one of the components of the cement. Tests were also performed with concrete containing materials that were specially prepared to simulate SRP waste sludges. These materials were equimolar mixtures of hydrous oxides of $\mathrm{Fe}^{3+}$ and $\mathrm{Al}^{3^{+}}$or of $\mathrm{Fe}^{3+}$ and $\mathrm{Mn}^{4^{+}}$. The mixtures were prepared by hydroxide precipitation of the ions from neutral nitrate solutions. ${ }^{5}$ After precipitation, each mixture was washed several times and then dried. For all tests, the simulated wastes were $40 \mathrm{wt} \%$ of the dry cement-waste mixture.

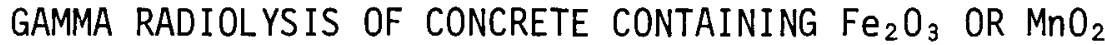

Concrete containing $40 \mathrm{wt} \%$ (dry basis) reagent-grade $\mathrm{Fe}_{2} \mathrm{O}_{3}$ or $\mathrm{MnO}_{2}$ as simulated waste was irradiated to determine the effects of radiation dose and intensity on the rate of gas production. Also, the effect of added $\mathrm{NO}_{3}{ }^{-}$or $\mathrm{NO}_{2}{ }^{-}$ions was investigated in the presence of these reagents. $\mathrm{NO}_{3}{ }^{-}$or $\mathrm{NO}_{2}{ }^{-}$ may be present in the washed and dried radioactive SRP waste because this waste is presently stored in a $\mathrm{NO}_{3}{ }^{-}$or $\mathrm{NO}_{2}{ }^{-}$solution. Another study ${ }^{9}$ has shown that direct radiolysis of $\mathrm{NO}_{3}{ }^{-}$leads to $\mathrm{O}_{2}$ formation. This $\mathrm{O}_{2}$ formation could be another source of radiolytic pressurization.

High and Low Dose Rate Tests in Absence of Added $\mathrm{NO}_{3}{ }^{-}$or $\mathrm{NO}_{2}{ }^{-}$

Both high and low dose rate tests established that $\mathrm{H}_{2}$ was the only gas produced. The initial production rate of $\mathrm{H}_{2}$ was dependent upon the dose rate; but, as the $\mathrm{H}_{2}$ pressure increased, a reaction removing $\mathrm{H}_{2}$ was initiated. Eventually, $\mathrm{H}_{2}$ reached a steady-state pressure. This steady-state pressure was also dependent upon the dose rate. At higher dose rates, higher steady-state pressures were achieved. Gas rolume and the waterto-cement ratio did not affect this steady-state pressure. Gas composition at the end of the tests showed that $\mathrm{O}_{2}$ from the air sealed with the concrete was consumed and $\mathrm{N}_{2}$ was unaffected.

Pressure changes from gamma radiolysis at different dose rates are shown in Figures 2, 3, and 4. Data for these tests are shown in Table 1 . The final gas compositions indicate that $\mathrm{N}_{2}$ was not significantly affected and that $\mathrm{O}_{2}$ was 60 to $80 \%$ consumed. This consumption accounts for the initial pressure 


\section{TABLE 1}

Data for Gamma Radiolysis of Concrete Containing $\mathrm{Fe}_{2} \mathrm{O}_{3}$ or $\mathrm{MnO}_{2}$ as Simulated Waste

\begin{tabular}{|c|c|c|c|c|c|c|c|}
\hline \multicolumn{4}{|c|}{ Materials Irradiated, $g$} & \multirow{2}{*}{$\begin{array}{l}\text { Gas } \\
\text { Volume, } \\
m L\end{array}$} & \multicolumn{3}{|c|}{$\begin{array}{l}\text { Final Gas } \\
\text { Composition, \% }\end{array}$} \\
\hline Oxide & & Cement & $\overline{\mathrm{H}_{2} \mathrm{O}}$ & & $\overline{H_{2}}$ & $\mathrm{O}_{2}$ & $\mathrm{~N}_{2}$ \\
\hline $\mathrm{Fe}_{2} \mathrm{O}_{3}{ }^{a}$ & 300 & 451 & 306 & 105 & 16.3 & 6.7 & 77.0 \\
\hline $\mathrm{MnO}_{2}{ }^{\mathrm{a}}$ & 369 & 554 & 228 & 112 & 6.9 & 4.9 & 88.2 \\
\hline $\mathrm{Fe}_{2} \mathrm{O}_{3}{ }^{b}$ & 96 & 144 & 99 & 124 & 82.2 & 6.8 & 11.0 \\
\hline $\mathrm{Fe}_{2} \mathrm{O}_{3}{ }^{\mathrm{C}}$ & 94 & 130 & 96 & 135 & 83.8 & 4.7 & 11.6 \\
\hline $\mathrm{Fe}_{2} \mathrm{O}_{3}{ }^{\mathrm{C}}$ & 93 & 139 & 95 & 141 & 85.9 & 6.6 & 9.8 \\
\hline $\mathrm{MnO}_{2} \mathrm{C}$ & 117 & 177 & 82 & 135 & 80.2 & 2.3 & 17.8 \\
\hline
\end{tabular}

a. Dose rate $=8.9 \times 10^{4} \mathrm{rads} / \mathrm{hr}$. Irradiation temperature $=40^{\circ} \mathrm{C}$.

b. Dose rate $=1.4 \times 10^{7} \mathrm{rads} / \mathrm{hr}$. Irradiation temperature $=45^{\circ} \mathrm{C}$.

c. Dose rate $=2.8 \times 10^{7} \mathrm{rads} / \mathrm{hr}$. Irradiation temperature $=45^{\circ} \mathrm{C}$.

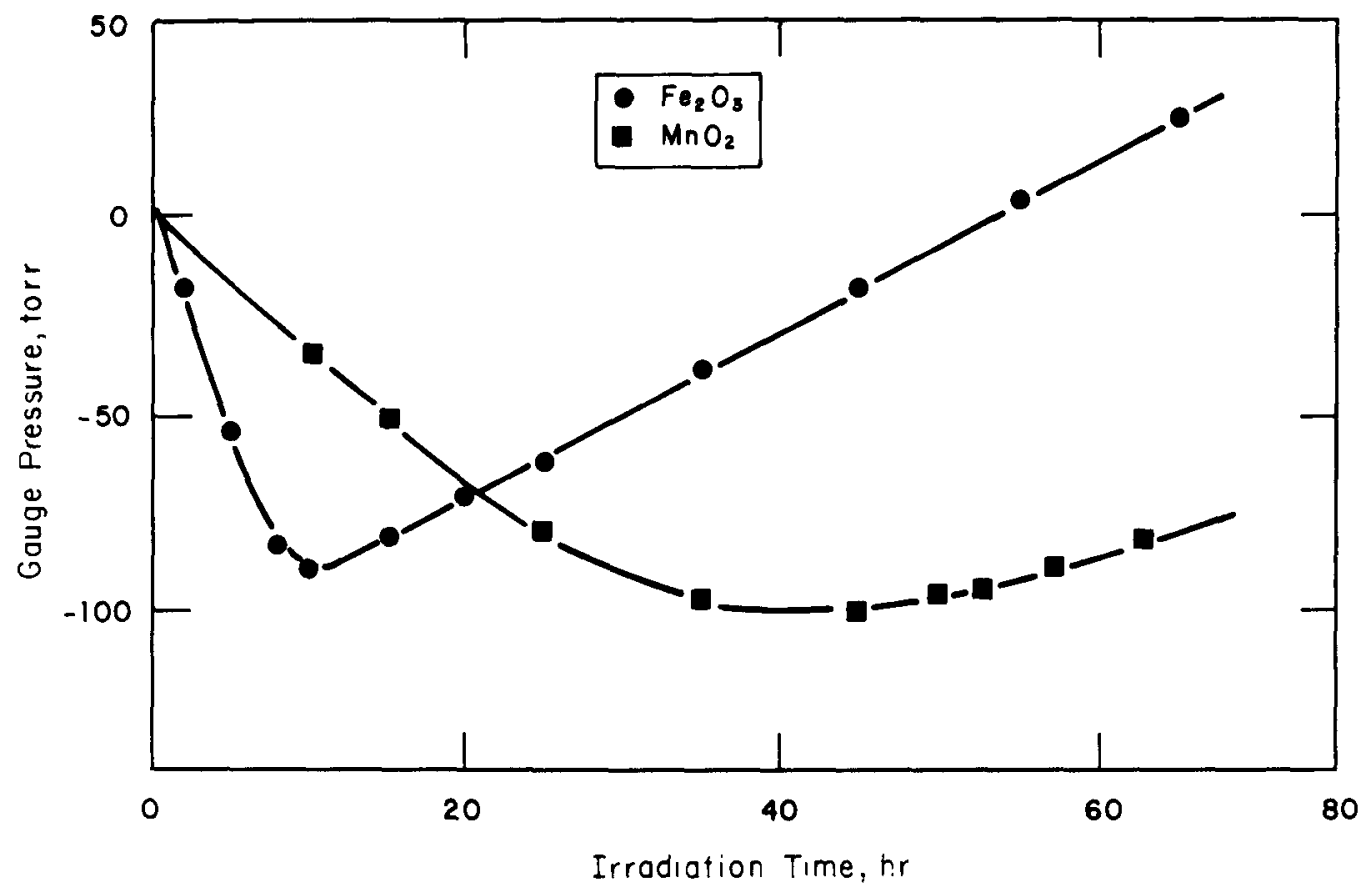

FIGURE 2. Pressure from Gamma Radiolysis at $8.9 \times 10^{4} \mathrm{rads} / \mathrm{hr}$ of Concrete Containing $\mathrm{Fe}_{2} \mathrm{O}_{3}$ or $\mathrm{MnO}_{2}$ as Simulated Waste 


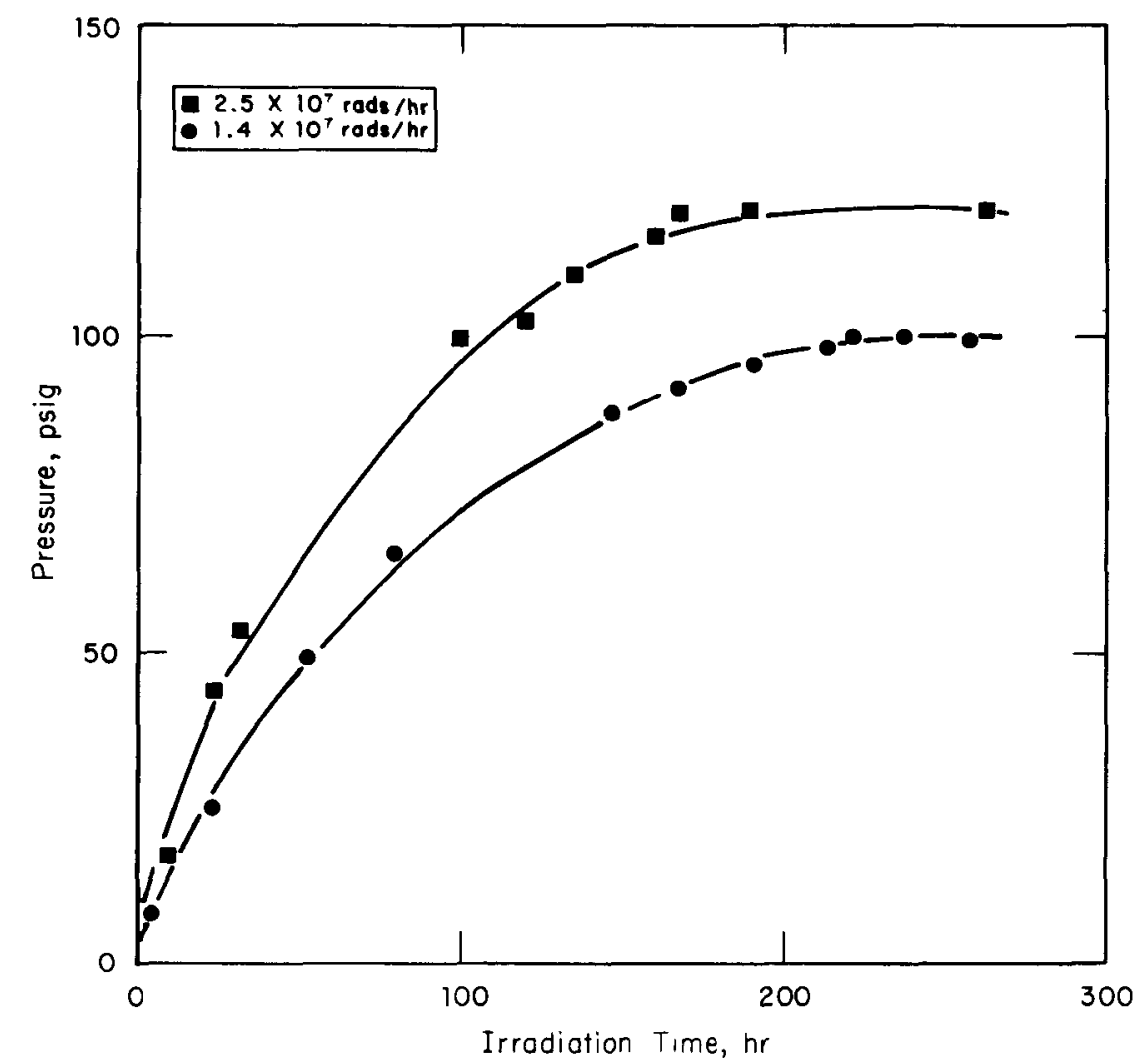

FIGURE 3. Pressure from Gamma Radiolysis at Two Dose Rates of Concrete Containing $\mathrm{Fe}_{2} \mathrm{O}_{3}$

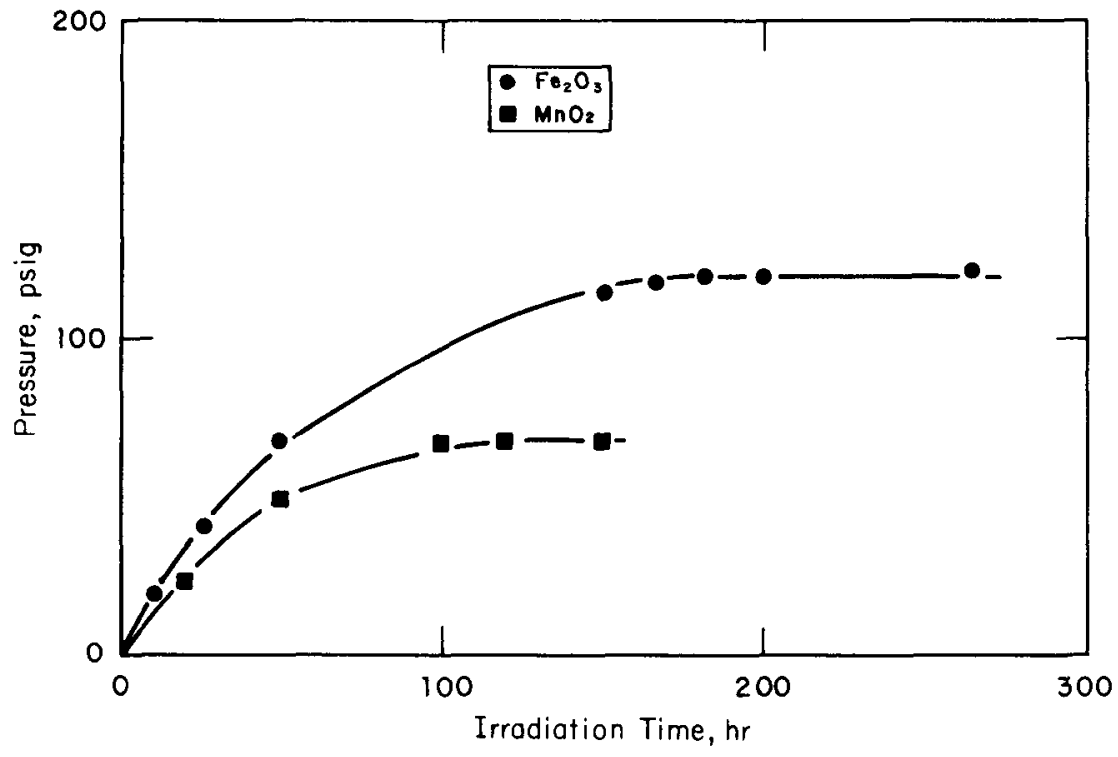

FIGURE 4. Pressure from Gamma Radiolys is at $2.8 \times 10^{7} \mathrm{rads} / \mathrm{hr}$ of Concrete Containing $\mathrm{Fe}_{2} \mathrm{O}_{3}$ or $\mathrm{MnO}_{2}$ as Simulated Waste 
decreases observed in the test at $8.9 \times 10^{4} \mathrm{rads} / \mathrm{hr}$ (Figure 2). $\mathrm{O}_{2}$ was consumed faster than $\mathrm{H}_{2}$ was produced; however, $\mathrm{O}_{2}$ was not completely consumed because of the long, small ID tube separating the irradiation container from the pressure gage and sampling valve. This small-diameter tube prevented $\mathrm{O}_{2}$ from diffusing into the radiation field where it could react. In a test where the entire gas volume was in the radiation field, $95 \%$ of the $\mathrm{O}_{2}$ was consumed.

Achievement of a steady-state pressure is evident from the tests at $1.4 \times 10^{7}$ and $2.5 \times 10^{7} \mathrm{rads} / \mathrm{hr}$ (Figures 3 and 4 ). Results indicate that the value of this final pressure is dependent upon the dose rate (Figure 3 ) and the composition of the wastes (Figure 4). The dose rate dependency of this steady-state pressure was examined at two lower dose rates, $8.9 \times 10^{4}$ and $3.9 \times 10^{5} \mathrm{rads} / \mathrm{hr}$. At these lower intensities, the irradiation time necessary to generate enough $\mathrm{H}_{2}$ to reach a steady-state pressure was several months. Thus, to achieve steady state in a shorter time, $\mathrm{H}_{2}$ was pressurized into the irradiation container until radiolytic pressurization ceased. Steady-state pressures determined at the four dose rates are shown in Figure 5.

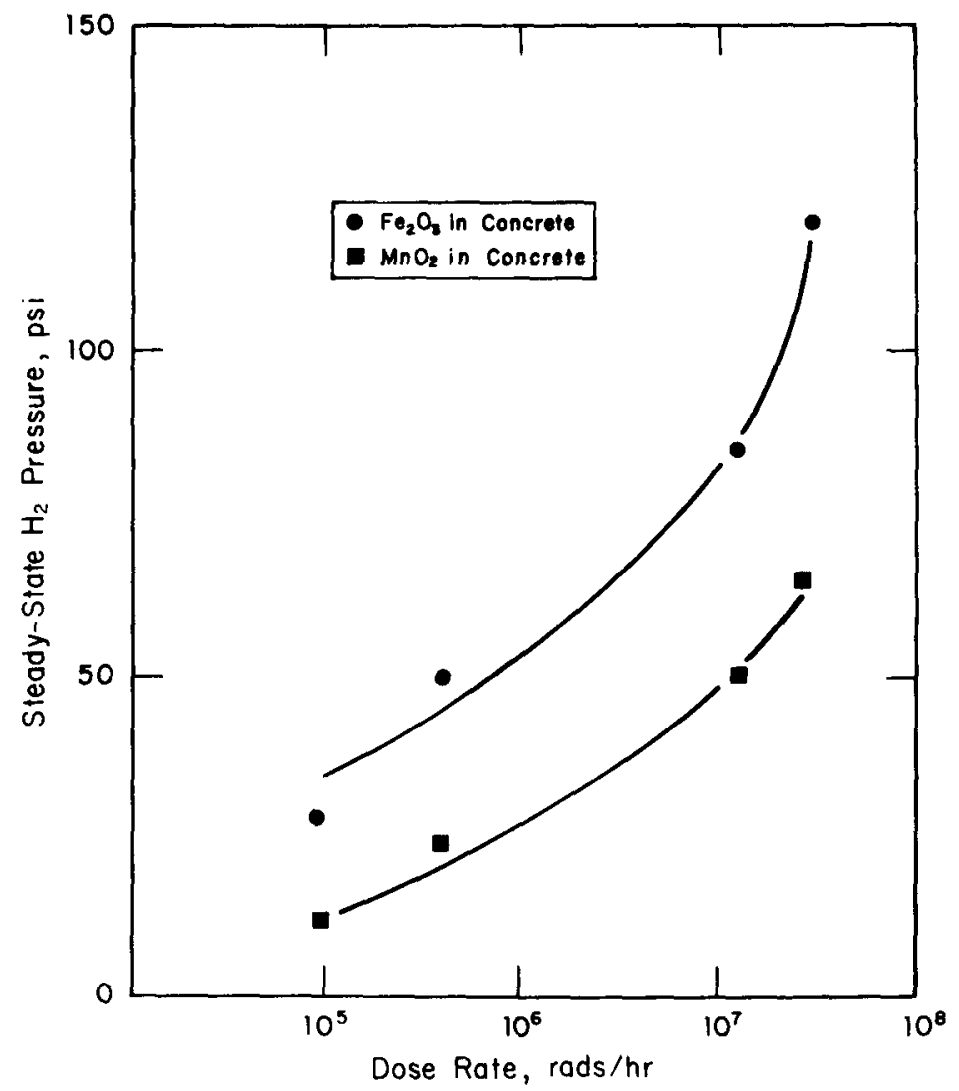

FIGURE 5. Effect of Dose Rate on Steady-State $\mathrm{H}_{2}$ Pressures 
Data in Table 2 show that gas volume and water-to-cement ratios (by weight) from 0.29 to 0.77 did not significantly affect the steady-state pressure. Because of the lack of an effect of gas volume, smaller amounts of $\mathrm{H}_{2}$ were produced in containers with smaller gas volumes. The water-to-cement ratios bracket those that give workability to the concrete.

\section{TABLE 2}

Effect of Gas Volume and Water-to-Cement Ratio on Steady-State $\mathrm{H}_{2}$ Pressures ${ }^{a}$

\begin{tabular}{|c|c|c|c|c|}
\hline$\frac{\text { Materials }}{\text { Cement }}$ & \multicolumn{2}{|c|}{ Irradiated, $g$} & $\begin{array}{l}\text { Free } \\
\text { Volume, } \\
m L\end{array}$ & $\begin{array}{l}\text { Equilibrium } \\
\mathrm{H}_{2} \text { Pressure, } \\
\text { psi }\end{array}$ \\
\hline 244 & 67 & 0.27 & 144 & 100 \\
\hline 199 & 55 & 0.28 & 167 & 105 \\
\hline 132 & 36 & 0.27 & 223 & 96 \\
\hline 225 & 95 & 0.40 & 138 & 102 \\
\hline 225 & 173 & 0.77 & 125 & 108 \\
\hline
\end{tabular}

a. Dose rate $=2.8 \times 10^{7} \mathrm{rads} / \mathrm{hr}$. Irradiation temperature $=45^{\circ} \mathrm{C}$.

b. Water-to-cement ratio.

Low Dose Rate Tests in Presence of Added $\mathrm{NO}_{3}^{-}$or $\mathrm{NO}_{2}^{-}$Ions

Low dose rate tests $\left(8.9 \times 10^{4} \mathrm{rads} / \mathrm{hr}\right)$ showed that added $\mathrm{NO}_{3}{ }^{-}$or $\mathrm{NO}_{2}{ }^{-}$did not lead to additional pressurization. $\mathrm{O}_{2}$ was still consumed, and $\mathrm{H}_{2}$ was still produced. However, small amounts of $\mathrm{N}_{2} \mathrm{O}$ were produced. At the high dose rate $\left(2.8 \times 10^{7} \mathrm{rads} / \mathrm{hr}\right)$, however, $\mathrm{O}_{2}$ was a product indicating a different radiolytic mechanism at this intensity. Also, a steady-state pressure was not achieved as it was when $\mathrm{NO}_{3}{ }^{-}$or $\mathrm{NO}_{2}{ }^{-}$was absent. $\mathrm{N}_{2} \mathrm{O}$ was also a product at this dose rate. The amount of $\mathrm{N}_{2} \mathrm{O}$ formed could be significantly decreased by lowering the amount of $\mathrm{NO}_{2}{ }^{-}$present.

Pressure changes resulting from gamma radiolysis of concrete containing $\mathrm{Fe}_{2} \mathrm{O}_{3}$ and $5 \mathrm{wt} \% \mathrm{NO}_{3}{ }^{-}$or $5 \mathrm{wt} \% \mathrm{NO}_{3}^{-}$and $2.5 \mathrm{wt} \% \mathrm{NO}_{2}{ }^{-}$ at $8.9 \times 10^{4} \mathrm{rads} / \mathrm{hr}$ are shown in Figure 6. Pressure change data in the absence of these ions are also included (Table 3). Data from gas analyses show that in all three tests, 80 to $90 \%$ of the $\mathrm{O}_{2}$ was consumed, and $\mathrm{N}_{2}$ was not significantly affected. Lower amounts of $\mathrm{H}_{2}$ were produced in the tests with $\mathrm{NO}_{3}{ }^{-}$or with $\mathrm{NO}_{3}{ }^{-}$ 
and $\mathrm{NO}_{2}^{-}$present. The ions scavenge the precursors of $\mathrm{H}_{2}$. These precursors are $\mathrm{H}$ atoms formed by radiolysis of the water. This scavenging process leads to chemical reduction of the $\mathrm{NO}_{3}{ }^{-}$or $\mathrm{NO}_{2}{ }^{-}$. Sufficient reduction would form $\mathrm{N}_{2} \mathrm{O}$, the other gaseous product observed. A larger amount of $\mathrm{N}_{2} \mathrm{O}$ formed when $\mathrm{NO}_{2}{ }^{-}$was present suggests that this ion is significant in the mechanism for $\mathrm{N}_{2} \mathrm{O}$ formation. Separate tests showed that lowering the $\mathrm{NO}_{2}{ }^{-}$content by a factor of 5 lowered the $\mathrm{N}_{2} \mathrm{O}$ production rate by a factor of about 2.5 .

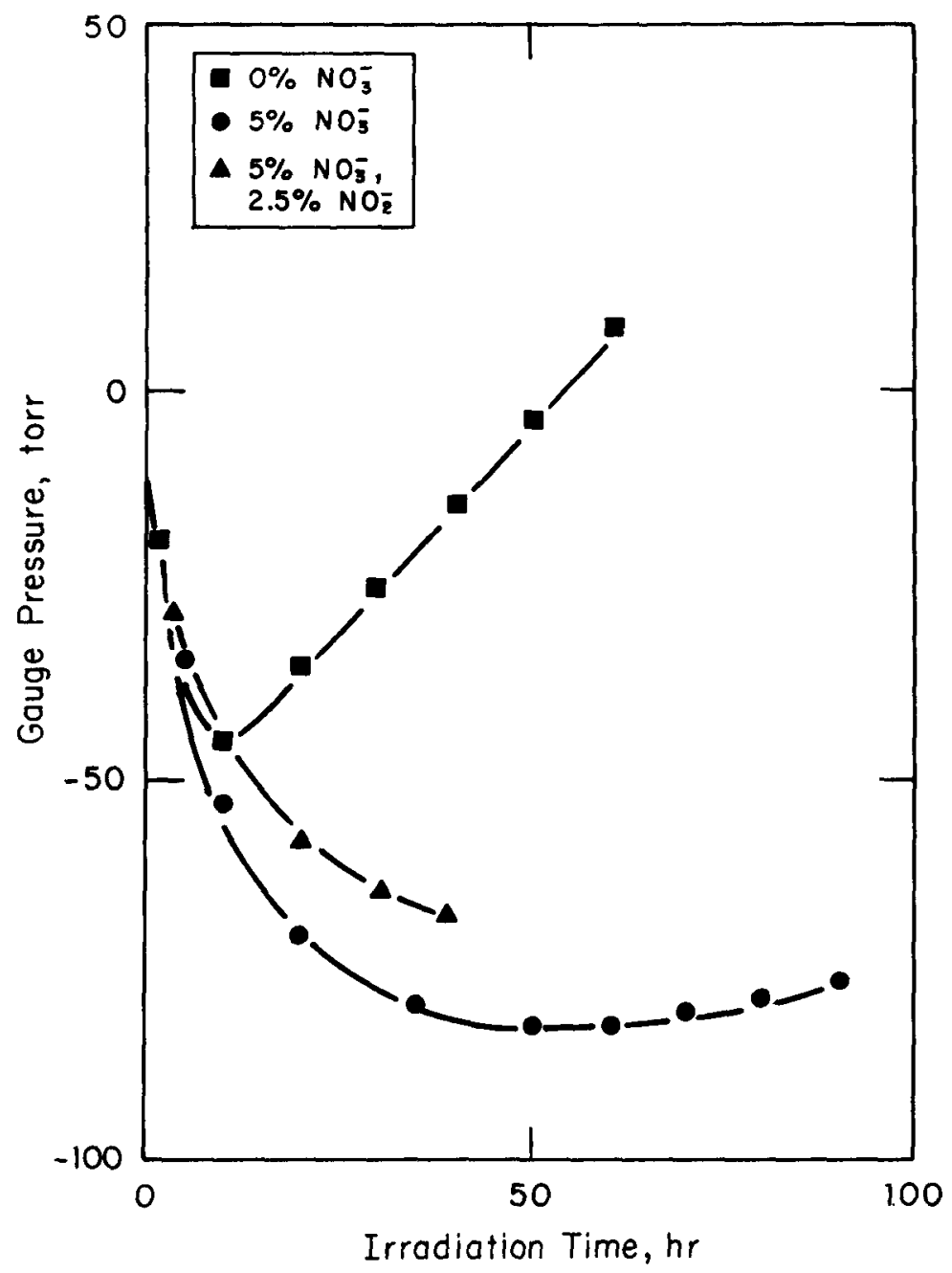

FIGURE 6. Pressure from Gamma Radiolysis at $8.9 \times 10^{4} \mathrm{rads} / \mathrm{hr}$ of Concrete Containing $\mathrm{Fe}_{2} \mathrm{O}_{3}$ with Sorbed $\mathrm{NO}_{3}{ }^{-}$and $\mathrm{NO}_{2}^{-}$Ions 
TABLE 3

Data for Gamma Radiolysis of Concrete Containing

$\mathrm{Fe}_{2} \mathrm{O}_{3}$ with Sorbed $\mathrm{NO}_{3}^{-}$or $\mathrm{NO}_{2}^{-}$Ions ${ }^{a}$

\begin{tabular}{|c|c|c|c|c|c|c|c|c|c|}
\hline \multicolumn{5}{|c|}{ Materials Irradiated, $g$} & \multirow{2}{*}{$\begin{array}{l}\text { Gas } \\
\text { Volume, } \\
m L\end{array}$} & \multicolumn{4}{|c|}{$\begin{array}{l}\text { Final Gas } \\
\text { Composition, \% }\end{array}$} \\
\hline Cement & $\mathrm{Fe}_{2} \mathrm{O}_{3}$ & $\mathrm{H}_{2} \mathrm{O}$ & $\mathrm{NO}_{3}-$ & $\mathrm{NO}_{2}-$ & & $\mathrm{H}_{2}$ & $\mathrm{O}_{2}$ & $\mathrm{~N}_{2}$ & $\mathrm{~N}_{2} \mathrm{O}$ \\
\hline 451 & 300 & 306 & 0 & 0 & 105 & 20.3 & 6.7 & 73.1 & 0.0 \\
\hline 467 & 312 & 297 & 15 & 0 & 85 & 8.5 & 2.3 & 88.8 & 0.4 \\
\hline 474 & 316 & 280 & 15 & 8 & 71 & 4.4 & 7.6 & 86.9 & 1.1 \\
\hline
\end{tabular}

a. Dose rate $=8.9 \times 10^{4} \mathrm{rads} / \mathrm{hr}$. Irradiation temperature $=41^{\circ} \mathrm{C}$.

In the two tests which contained $\mathrm{NO}_{3}{ }^{-}$or $\mathrm{NO}_{2}{ }^{-}$and $\mathrm{NO}_{3}{ }^{-}$ions, radiolytic pressurization was stopped by pressurizing the system with about 30 psi $\mathrm{H}_{2}$. This pressure agrees with that predicted in Figure 5 at this dose rate. Because pressurization was stopped by $\mathrm{H}_{2}$ addition, $\mathrm{NO}_{3}{ }^{-}$and $\mathrm{NO}_{2}{ }^{-}$. ions did not significantly affect the backreaction leading to steady-state pressures. Achievement of a steady-state pressure indicates that $\mathrm{O}_{2}$ was not a radiolytic product at $8.9 \times 10^{4} \mathrm{rads} / \mathrm{hr}$. Finally, achievement of the steadystate pressure showed that $\mathrm{N}_{2} \mathrm{O}$ production was stopped by the presence of $\mathrm{H}_{2}$. Apparently, the intermediate leading to $\mathrm{N}_{2} \mathrm{O}$ formation can be scavenged by large pressures of $\mathrm{H}_{2}$.

Results of a test at a much higher dose rate $\left(2.8 \times 10^{7}\right.$ $\mathrm{rads} / \mathrm{hr}$ ) with concrete containing $1 \mathrm{wt} \% \mathrm{NO}_{3}{ }^{-}$are shown in Figure 7. Data obtained in the absence of $\mathrm{NO}_{3}{ }^{-}$are also presented. At the end of the test with $\mathrm{NO}_{3}{ }^{-}$present, the gas composition was $64 \% \mathrm{H}_{2}, 25 \% \mathrm{O}_{2}, 11.5 \% \mathrm{~N}_{2}$, and $0.5 \% \mathrm{~N}_{2} \mathrm{O}$. Similar results were obtained with concrete containing $1 \mathrm{wt} \% \mathrm{NO}_{3}{ }^{-}$and 1 wt $\% \mathrm{NO}_{2}{ }^{-}$, except that in presence of $\mathrm{NO}_{2}{ }^{-}$, more $\mathrm{N}_{2} \mathrm{O}$ was produced. The gas composition data indicated that $\mathrm{O}_{2}$ was now a product of the radiolysis along with $\mathrm{H}_{2}$ and $\mathrm{N}_{2} \mathrm{O}$. Based on the initial and fina $1 \mathrm{O}_{2} / \mathrm{N}_{2}$ ratios, the ratio of evolved $\mathrm{O}_{2}$ to $\mathrm{H}_{2}$ was 0.3 . These results are in contrast to those at the lower dose rate $\left(8.9 \times 10^{4}\right.$ $\operatorname{rads} / \mathrm{hr}$ ), where $\mathrm{O}_{2}$ was consumed rather than produced. $\mathrm{O}_{2}$ production suggests a different radiolytic mechanism at the high dose rate.

Another difference caused by $\mathrm{NO}_{3}{ }^{-}$in the high dose rate test is that a steady-state pressure is not reached. This difference (Figure 7) also suggests that a different radiolytic mechanism occurred at the high dose rate. A final test was performed to determine whether $\mathrm{O}_{2}$ was an initial product or a secondary product 
resulting from the large radiation dose $\left(3.8 \times 10^{9} \mathrm{rads}\right)$. Two samples of concrete and $\mathrm{Fe}_{2} \mathrm{O}_{3}$, one with $5 \mathrm{wt} \% \mathrm{NO}_{3}{ }^{-}$and one without added $\mathrm{NO}_{3}{ }^{-}$, were irradiated at the high dose rate $\left(2.8 \times 10^{7}\right.$ rads/hr) in containers with small void volumes. The concrete samples were irradiated to $8 \times 10^{6}$ rads. This dose caused about $80 \% \mathrm{O}_{2}$ consumption at the low dose rate (Figure 6). Analysis of the resulting gases showed that $\mathrm{O}_{2}$ was $92 \%$ consumed in the absence of $\mathrm{NO}_{3}{ }^{-}$, but $\mathrm{O}_{2}$ was increased by $43 \%$ when $\mathrm{NO}_{3}{ }^{-}$was present. The data establish that $\mathrm{O}_{2}$, at the high dose rate, resulted from the presence of $\mathrm{NO}_{3}^{-}$rather than from the large radiation dose.

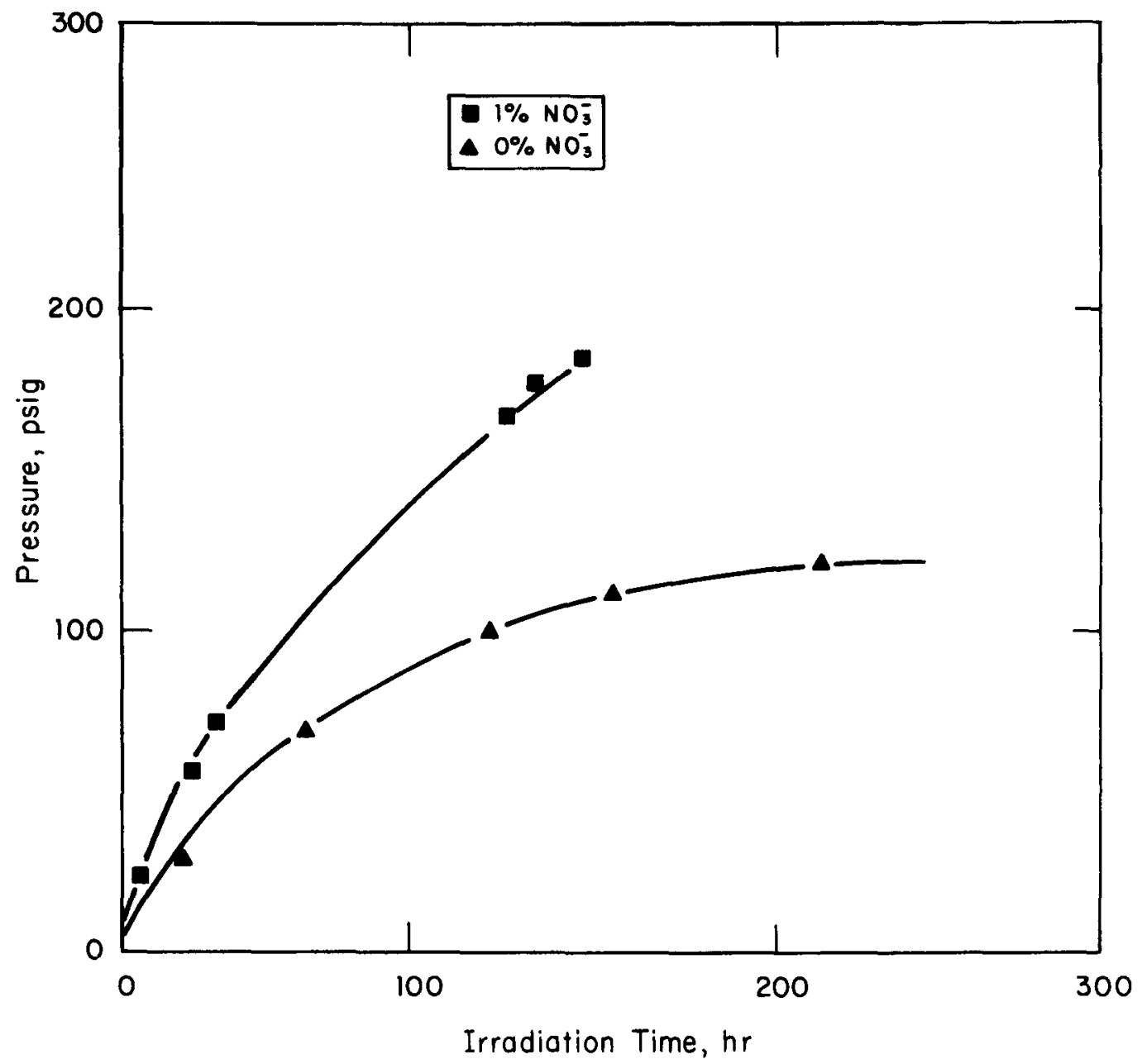

FIGURE 7. Pressure from Gamma Radiolysis at $2.8 \times 10^{7} \mathrm{rads} / \mathrm{hr}$ of Concrete Containing $\mathrm{Fe}_{2} \mathrm{O}_{3}$ with Sorbed $\mathrm{NO}_{3}{ }^{-}$Ions 
Concrete containing material that simulated SRP waste sludges was irradiated. This material contained equimolar mixtures of hydrous oxides of $\mathrm{Fe}^{3+}$ and $\mathrm{Al}^{3+}$ or hydrous oxides of $\mathrm{Fe}^{3+}$ and $\mathrm{Mn}^{4+}$. The oxides were prepared by hydroxide precipitation of the respective metal ions from $\mathrm{NO}_{3}{ }^{-}$solutions. These simulated wastes were identical to those used in other studies evaluating concrete ${ }^{5}$ or glass $^{6}$ as solidification matrices. Results of irradiation of samples containing $40 \mathrm{wt} \%$ (dry basis) of the simulated wastes at both $10 \mathrm{w}-\left(8.9 \times 10^{4} \mathrm{rads} / \mathrm{hr}\right)$ and hi.gh $\left(1.4 \times 10^{7} \mathrm{rads} / \mathrm{hr}\right)$ dose rates were not significantly different from those with concrete containing reagent-grade $\mathrm{Fe}_{2} \mathrm{O}_{3}$ with added $\mathrm{NO}_{3}{ }^{-}$and $\mathrm{NO}_{2}{ }^{-}$ions.

At the low dose rate (Figure 8 , Table 4 ), the pressure initially decreased because almost $80 \%$ of the $\mathrm{O}_{2}$ was consumed. Hydrogen and a trace of $\mathrm{N}_{2} \mathrm{O}$ were produced. Nitrogen was not affected. With both types of simulated wastes, pressurization could be stopped by adding 36-psi hydrogen.

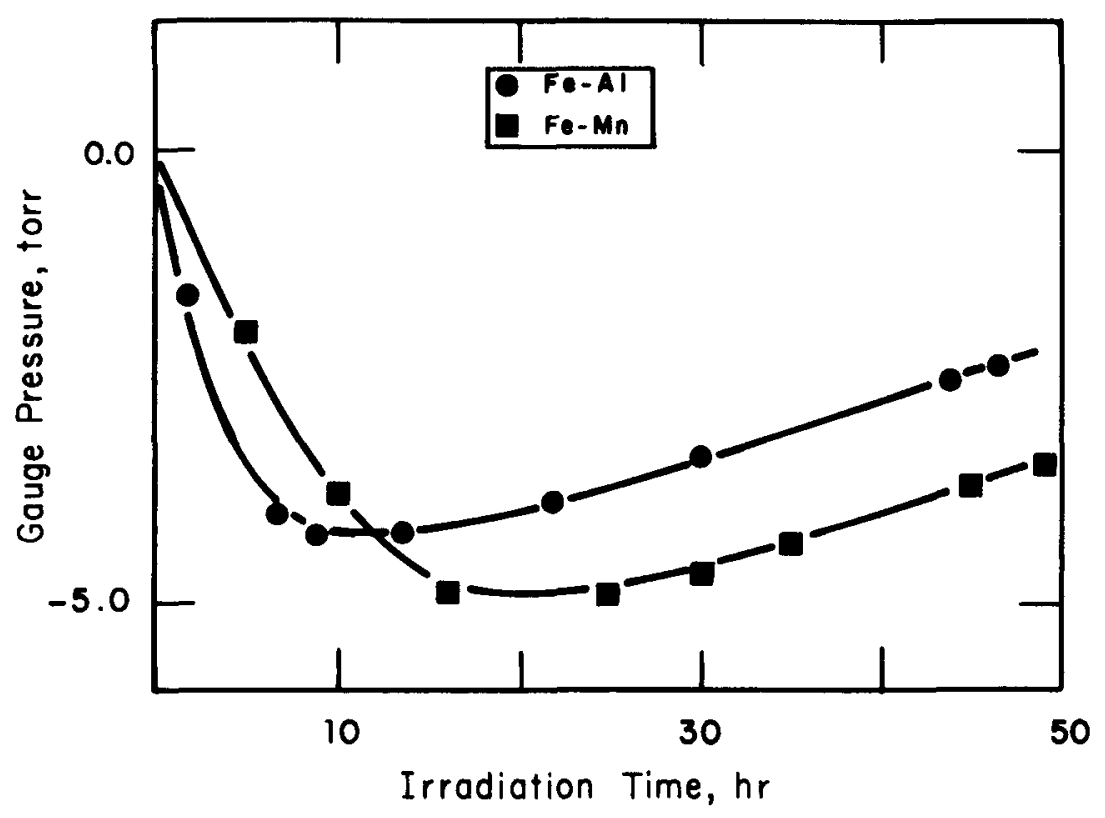

FIGURE 8. Pressure from Gamma Radiolysis at $8.9 \times 10^{4} \mathrm{rads} / \mathrm{hr}$ of Concrete Containing SRP Simulated Wastes 
At the high dose rate (Figure 9 , Table 4), a steady-state pressure was not achieved as it was with concrete containing only $\mathrm{Fe}_{2} \mathrm{O}_{3}$ or $\mathrm{MnO}_{2}$. Also, $\mathrm{O}_{2}$ was a significant product. The evolved gas was $34 \%$ oxygen and $66 \%$ hydrogen. These results suggest that $\mathrm{NO}_{3}{ }^{-}$ions were present in the simulated wastes. The presence of these ions is not unexpected because the simulated wastes were prepared by precipitation of $\mathrm{Fe}-\mathrm{Al}$ or $\mathrm{Fe}-\mathrm{Mn}$ ions from nitrate solutions.

TABLE 4

Data for Gamma Radiolys is of Concrete Containing SRP Simulated Wastes ${ }^{a}$

\begin{tabular}{|c|c|c|c|c|c|c|c|c|}
\hline \multicolumn{4}{|c|}{ Materials Irradiated, $g$} & \multirow{2}{*}{$\begin{array}{l}\text { Gas } \\
\text { Volume, } \\
m L\end{array}$} & \multicolumn{4}{|c|}{$\begin{array}{l}\text { Final Gas } \\
\text { Composition, \% }\end{array}$} \\
\hline Wastes & & Cement & $\mathrm{H}_{2} \mathrm{O}$ & & $\overline{H_{2}}$ & $\mathrm{O}_{2}$ & $\mathrm{~N}_{2}$ & $\overline{\mathrm{N}_{2} \mathrm{O}}$ \\
\hline $\mathrm{Fe}-\mathrm{Mn}^{a}$ & 228 & 432 & 273 & 110 & 11.8 & 5.0 & 82.9 & 0.3 \\
\hline $\mathrm{Fe}-\mathrm{A} 1^{a}$ & 317 & 476 & 313 & 123 & 9.1 & 5.4 & 85.5 & 0.0 \\
\hline $\mathrm{Fe}-\mathrm{Mn}^{b}$ & 88.0 & 132 & 89 & 148 & 77.1 & 13.8 & 9.2 & 0.0 \\
\hline $\mathrm{Fe}-\mathrm{A1}{ }^{b}$ & 88.5 & 133 & 91 & 140 & 60.8 & 32.9 & 6.3 & 0.0 \\
\hline
\end{tabular}

a. Dose rate $=8.9 \times 10^{4} \mathrm{rads} / \mathrm{hr}$. Irradiation temperature $=41^{\circ} \mathrm{C}$.

b. Dose rate $=1.4 \times 10^{7} \mathrm{rads} / \mathrm{hr}$. Irradiation temperature $=45^{\circ} \mathrm{C}$.

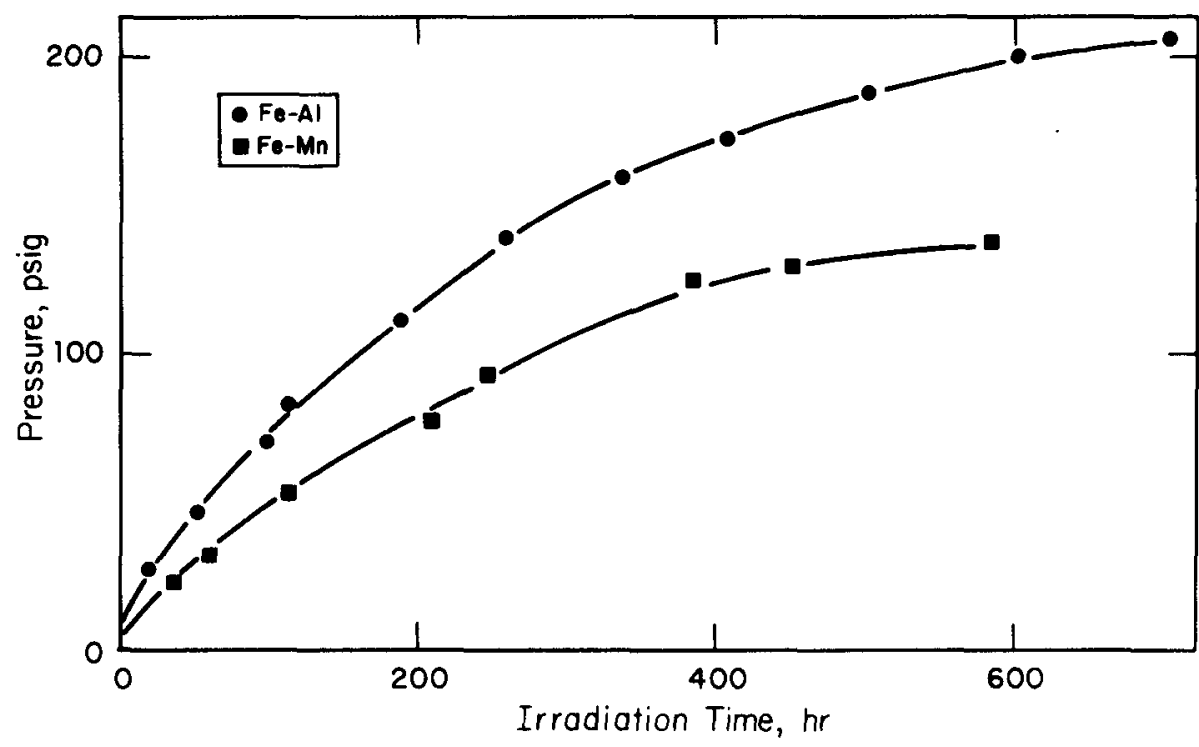

FIGURE 9. Pressure from Gamma Radiolysis at $1.4 \times 10^{7} \mathrm{rads} / \mathrm{hr}$ of Concrete Containing SRP Simulated Wastes 
If concrete is used to solidify SRP wastes, a set retarder may be added to the cement-sludge mixture. The set retarder will lengthen the time for the concrete to harden and will allow more time for pouring the paste from a mixing tank into a final storage container. Several set retarders have been evaluated. ${ }^{10}$ Many are organic compounds that may generate $\mathrm{H}_{2}$ or $\mathrm{CO}_{2}$ when irradiated. To determine if an organic set retarder would produce gases when irradiated in concrete, samples of concrete containing $\mathrm{Fe}-\mathrm{Al}$ simulated waste and ascorbic acid $\left(\mathrm{C}_{6} \mathrm{H}_{8} \mathrm{O}_{6}\right)$ as a typical organic set retarder were irradiated. In a low dose rate test (Figure 10, Table 5), $\mathrm{O}_{2}$ was consumed; and $\mathrm{H}_{2}$ was produced as in the tests without a set retarder. However, pressurization could not be stopped as it was in absence of set retarder. In fact, addition of $60 \mathrm{psi} \mathrm{H}_{2}$, the maximum tested, did not affect the pressurization rate.

In a high dose rate test, the initial pressurization was faster than that when the retarder was absent (Figure 11, Table 5). A steady-state pressure of about 150 psig was achieved when the retarder was present. Also, gas composition data (Table 5) show that $\mathrm{O}_{2}$ was not a product.

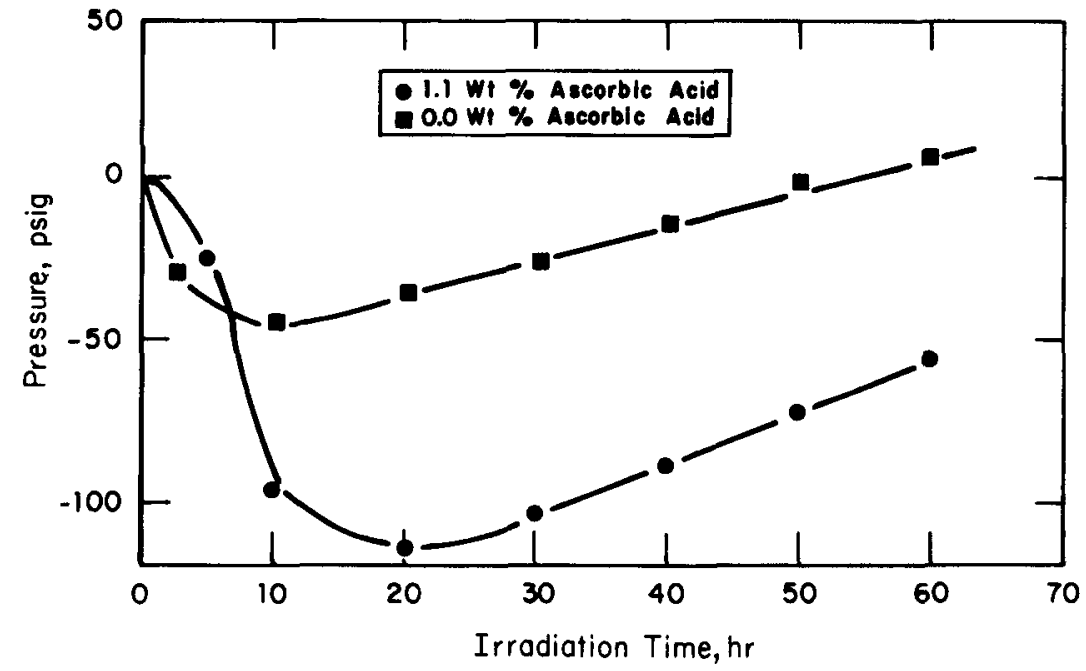

FIGURE 10. Pressure from Gamma Radiolysis at $8.9 \times 10^{4} \mathrm{rads} / \mathrm{hr}$ of Concrete Containing Fe-Al Simulated Waste and Ascorbic Acid Set Retarder 
TABLE 5

Data for Gamma Radiolysis of Concrete Containing Fe-Al

Simulated Waste and Ascorbic Acid Set Retardera

Dose Rate, Materials Irradiated, $g$
$\begin{aligned} & \text { rads/hr } \\ & \text { Oxide Cement } \mathrm{H}_{2} \mathrm{O} \mathrm{C}_{6} \mathrm{H}_{8} \mathrm{O}_{6}\end{aligned} \frac{\text { Gal }}{\mathrm{mL}}$
$8.9 \times 10^{4}$
329
493
$294 \quad 5.3$
60
10.8
$4.7 \quad 84.5$
$8.9 \times 10^{4} \quad 300$
451
$306 \quad 0.0$
105
7.3
$9.7 \quad 83.0$
$1.4 \times 10^{7} \quad 85 \quad 128$
$\begin{array}{ll}83 & 1.5\end{array}$
140
$\begin{array}{lll}89.8 & 0.8 & 9.0\end{array}$
$1.4 \times 10^{7}$
$84 \quad 126$
840.0
156
$\begin{array}{ll}76.7 & 14.4\end{array}$
8.9

a. Irradiation temperature $=40$ to $50^{\circ} \mathrm{C}$.

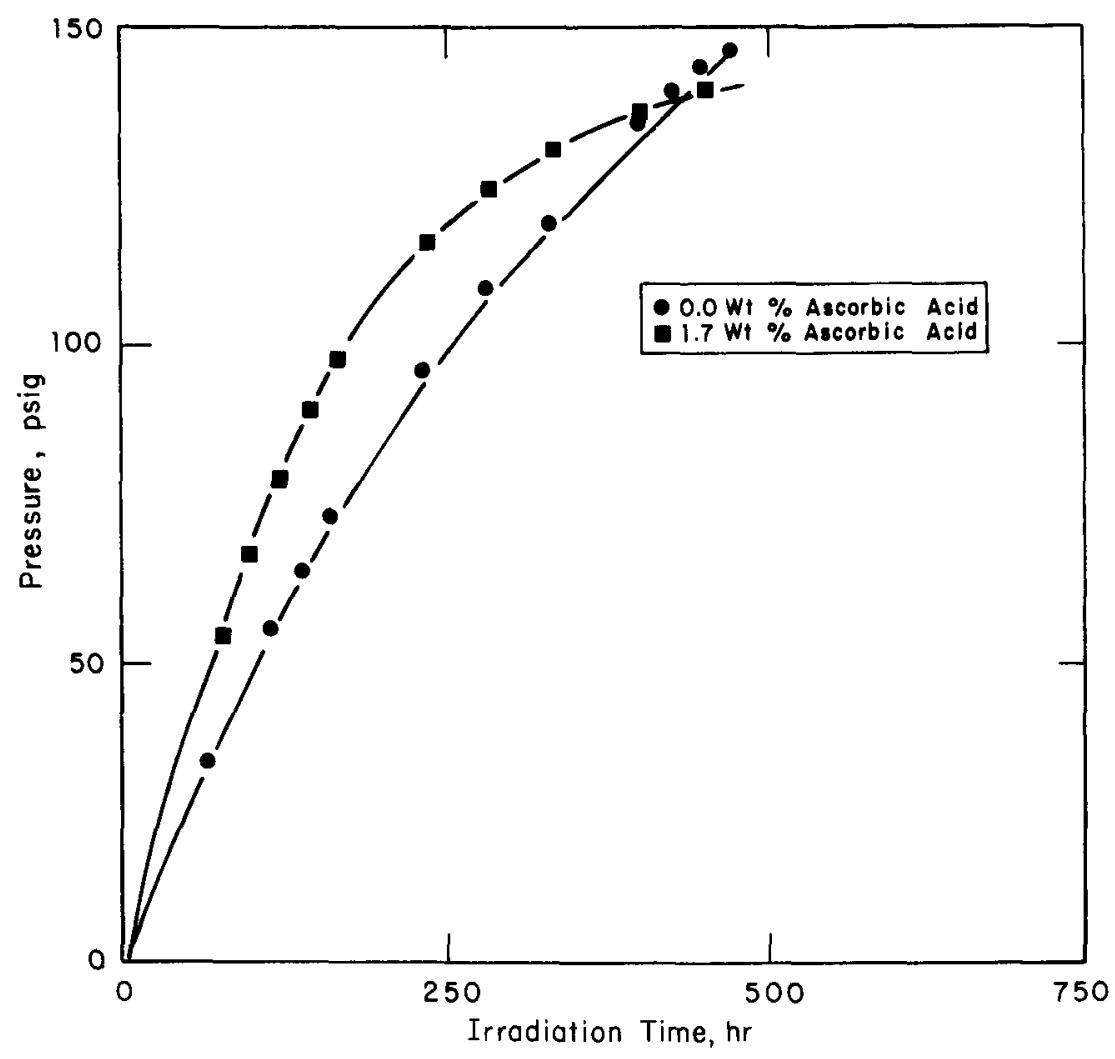

FIGURE 11. Pressure from Gamma Radiolys is at $1.4 \times 10^{7} \mathrm{rads} / \mathrm{hr}$ of Concrete Containing Fe-Al Simulated Waste and Ascorbic Acid Set Retarder 
The low dose rate results show that if an organic set retarder is used in the waste solidification process, an additional source of $\mathrm{H}_{2}$ pressurization will be present at low dose rates. The high dose rate results indicate that a steady-state pressure may be reached in containers of SRP concrete waste forms, but the pressure may be about 150 psig.

\section{EXPERIMENTAL PROCEDURES FOR GAMMA RADIOLYSIS TESTS}

Samples were irradiated at $8.9 \times 10^{4} \mathrm{rads} / \mathrm{hr}$ with a Gammace $11^{*}-220{ }^{60} \mathrm{Co}$ source at an ambient temperature of $40^{\circ} \mathrm{C}$. The irradiation containers were 500-mL glass bottles. In a separate container, water was added to the cement-simulated waste mixture (40 wt $\%$ waste) until good workability was attained (water-to-cement ratios about 0.3 by weight). The mixture was then poured into the glass bottle and allowed to cure for at least 20 hours.

During irradiation, the bottle was attached to 5 feet of 1/8-inch copper tubing that extended out of the radiation field to a sampling valve, a mercury manometer, and a recording strain gage pressure transducer. Sensitivity of the transducer was $0.43 \mathrm{torr} / \mathrm{mm}$ of chart response. Dose rates in the concrete were measured with the Fricke dosimeter. ${ }^{1}$ Minor corrections for differences between the electron densities of the solution and concrete were not applied.

After irradiation, the gas was sampled for analysis by expanding it into an evacuated sampler that had a much larger volume than that of the irradiation container and associated equipment. This expansion ensured that almost all the gas was removed, and a representative sample was obtained for analysis. Preliminary tests had shown that the copper tubing prevented complete mixing of the evolved gas with the air already present in the system. The gas in the sampler was compressed to atmospheric pressure and analyzed by gas chromatography. Free volume in the radiolysis container and associated equipment was determined by expanding a known amount of air into the volume and measuring the resulting pressure.

$\overline{\text { * Atomic Energy }}$ of Canada, Ltd., Ottawa, Canada. 
Samples were irradiated at $1.4 \times 10^{7} \mathrm{rads} / \mathrm{hr}$ and $2.8 \times 10^{7}$ $\mathrm{rads} / \mathrm{hr}$ with a ${ }^{60} \mathrm{Co}$ source submerged in 20 feet of water. Temperature during irradiation was 40 to $50^{\circ} \mathrm{C}$. These samples were cast into $3.5-\mathrm{cm}-\mathrm{ID} \times 18.5-\mathrm{cm}-\mathrm{tall}$ glass test tubes. Again, minimum set time was 20 hours. During irradiation, the glass tubes were in a steel container that was attached to about 25 feet of $1 / 8$-inch-OD steel tubing. The tubing extended above the water to a sampling valve and pressure gage. Dose rates to the samples were determined by irradiating film dosimeters in a small tube in the concrete. ${ }^{12}$ Methods for sampling and analyzing the gas and for determining the free volume were identical to those described previously.

\section{ALPHA RADIOLYSIS OF CONCRETE CONTAINING SRP SIMULATED WASTES}

Radioactive SRP wastes contain alpha emitters, such as ${ }^{238} \mathrm{Pu}$
and ${ }^{2{ }^{39}} \mathrm{Pu}$. Because alpha radiolysis can produce different effects than gamma radiolysis, concrete samples were irradiated with alpha particles. $2{ }^{4} \mathrm{Cm}$ was used as the radiation source. Concrete samples containing 40 wt \% (dry basis) SRP simulated wastes and $2{ }^{4} \mathrm{Cm}$ were prepared in steel tubes that could be sealed to pressure gages and sampling valves. The range of the alpha particles in concrete is about $0.01 \mathrm{~mm}$; thus, all the alpha energy was absorbed by the sample. In all the tests, $7.2 \mathrm{~g}$ of cement and $4.8 \mathrm{~g}$ of simulated wastes were used. A known amount of ${ }^{244} \mathrm{Cm}$ dissolved in the water was used to make the concrete. The significant results were that both $\mathrm{O}_{2}$ and $\mathrm{H}_{2}$ were products $\left(\mathrm{O}_{2} / \mathrm{H}_{2}\right.$ ratio varied from 0.2 to 0.5 ), and that a steady-state pressure was not achieved up to 200 psi, which was the maximum pressure tested. These results agree with those observed in alpha radiolysis of another type of concrete in another study. ${ }^{3}$

Results of three alpha radiolysis tests are shown in Figure 12 and Table 6 . For these tests, a known amount of ${ }^{244} \mathrm{Cm}$ was dispersed as a $\mathrm{Cm}_{2}\left(\mathrm{SO}_{4}\right)_{3}$ solution in a mixture of cement and $\mathrm{Fe}-\mathrm{Mn}$ or $\mathrm{Fe}-\mathrm{Al}$ waste. Mixing was performed in a steel test tube $(0.9 \mathrm{~cm}$ ID $\times 10 \mathrm{~cm}$ long). After the concrete had cured 20 hours, the tube was sealed to a pressure gage and sampling valve. At the end of the test, the gas was sampled and analyzed, and the gas volume determined as previously described for the gamma radiolysis tests. Partial pressures before and after the test were compared. The pressures showed that $\mathrm{N}_{2}$ did not change, and $\mathrm{O}_{2}$ and $\mathrm{H}_{2}$ were produced. The ratio of evolved $\mathrm{O}_{2}$ to $\mathrm{H}_{2}$ for the three tests was 0.4 . 


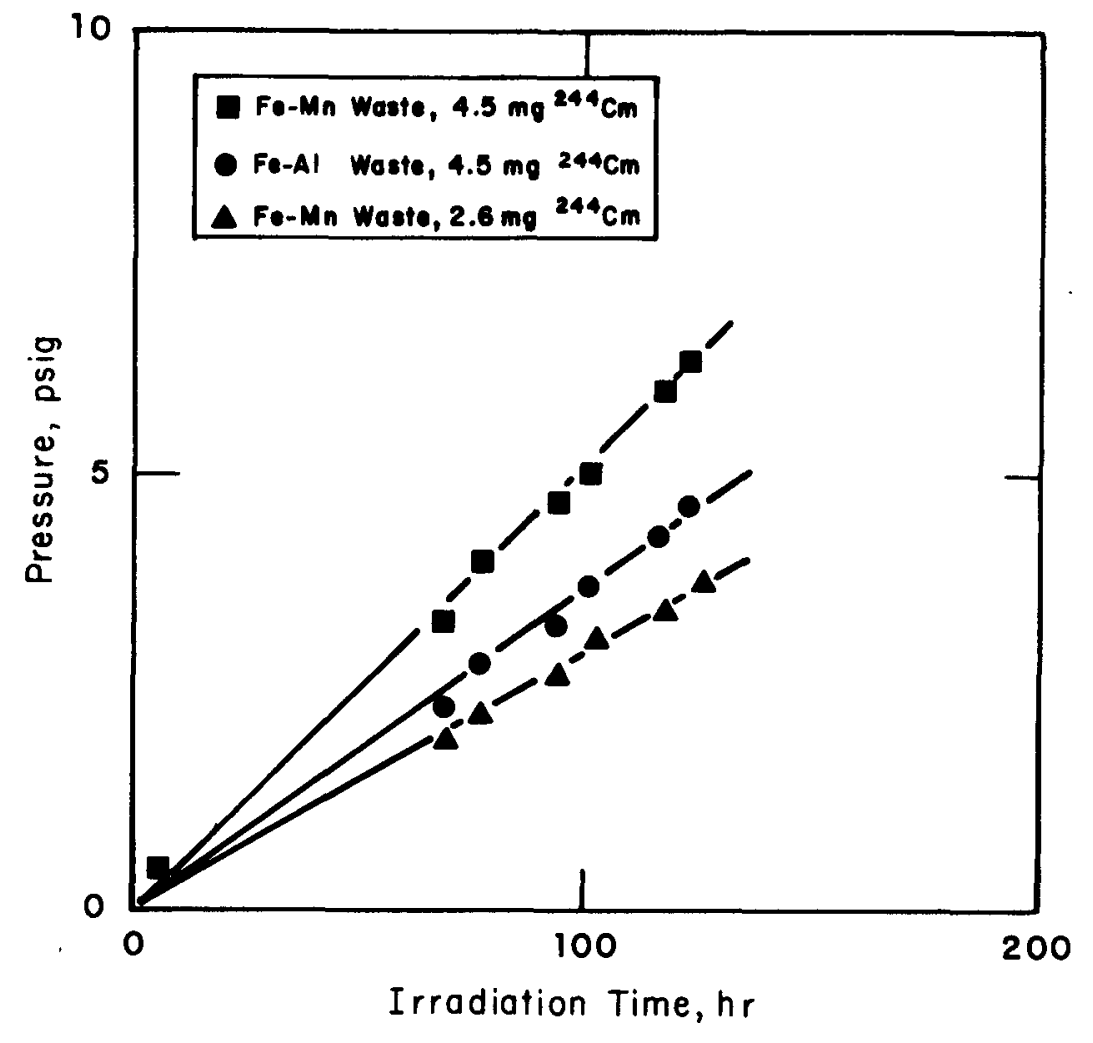

FIGURE 12. Pressure from Short-Term Alpha Radiolys is of Concrete Containing SRP Simulated Wastes

TABLE 6

Data for Alpha Radiolysis of Concrete Containing SRP Simulated Wastes ${ }^{a}$

\begin{tabular}{|c|c|c|c|c|c|c|c|c|c|}
\hline $244 \mathrm{~cm}$, & Materia & & radiate & & Dose Rate, & $\begin{array}{l}\text { Gas } \\
\text { Volume, }\end{array}$ & $\begin{array}{l}\text { Finat } \\
\text { Compo }\end{array}$ & $\begin{array}{l}\text { Gas } \\
\text { ition }\end{array}$ & $\%$ \\
\hline & Wastes & & Cement & Water & $e V / h r$ & & $\overline{H_{2}}$ & $\mathrm{O}_{2}$ & $N_{2}$ \\
\hline .5 & $\mathrm{Fe}-\mathrm{Al}$ & 4.8 & 7.2 & $b$ & $2.8 \times 10^{20}$ & 12.0 & 18.2 & 21.9 & 59.9 \\
\hline .5 & $\mathrm{Fe}-\mathrm{Mn}$ & 4.8 & 7.2 & $b$ & $2.8 \times 10^{20}$ & 11.9 & 19.2 & 22.1 & 58.7 \\
\hline .6 & $\mathrm{Fe}-\mathrm{Mn}$ & 4.8 & 7.2 & $b$ & $1.6 \times 10^{20}$ & 8.1 & 15.6 & 21.4 & 63.0 \\
\hline
\end{tabular}

a. Irradiation temperature $=23^{\circ} \mathrm{C}$.

$b$. The amount of water was not measured. Sufficient water was added to get a paste with good workability. 
To determine the effect of higher pressures on the pressurization rate, the test with Fe-Mn waste and $4.5 \mathrm{mg} 244 \mathrm{Cm}$ was monitored for a much longer time. Over a period of about 4.5 months, the pressure increased almost linearly to $200 \mathrm{psi}$ (Figure 13). This increase indicated little effect of pressure on the pressurization rate. The dose rate in this test which was $4 \times 10^{5} \mathrm{rads} / \mathrm{hr}$ was calculated by using $5.8 \mathrm{MeV}$ as the energy of the alpha particle and $1.8 \times 10^{11}$ alpha/(min-mg) for the specific activity of $24{ }^{4} \mathrm{Cm} .{ }^{14}$ For gamma radiolysis, a steadystate pressure of about $50 \mathrm{psi}$ is predicted at this dose rate (Figure 5). Failure to achieve a steady-state pressure reveals a difference between gamma and alpha radiolysis.

Steady state was not reached with alpha radiolysis because of an increase in the efficiency of the $\mathrm{H}_{2}$ production reaction and a decrease in that for the $\mathrm{H}_{2}$ removal reaction. Gas composition at the end of the long-term test was $62 \% \mathrm{H}_{2}, 32 \% \mathrm{O}_{2}$, and $6 \% \mathrm{~N}_{2}$. The respective partial pressures before and after the test showed that $\mathrm{N}_{2}$ did not change, and $\mathrm{O}_{2}$ and $\mathrm{H}_{2}$ were produced in the ratio of 0.5 to 1 . Alpha radiolysis decomposed water in the concrete to stoichiometric quantities of $\mathrm{H}_{2}$ and $\mathrm{O}_{2}$. The reason for less than a stoichiometric amount of $\mathrm{O}_{2}$ being produced in the other tests is not known.

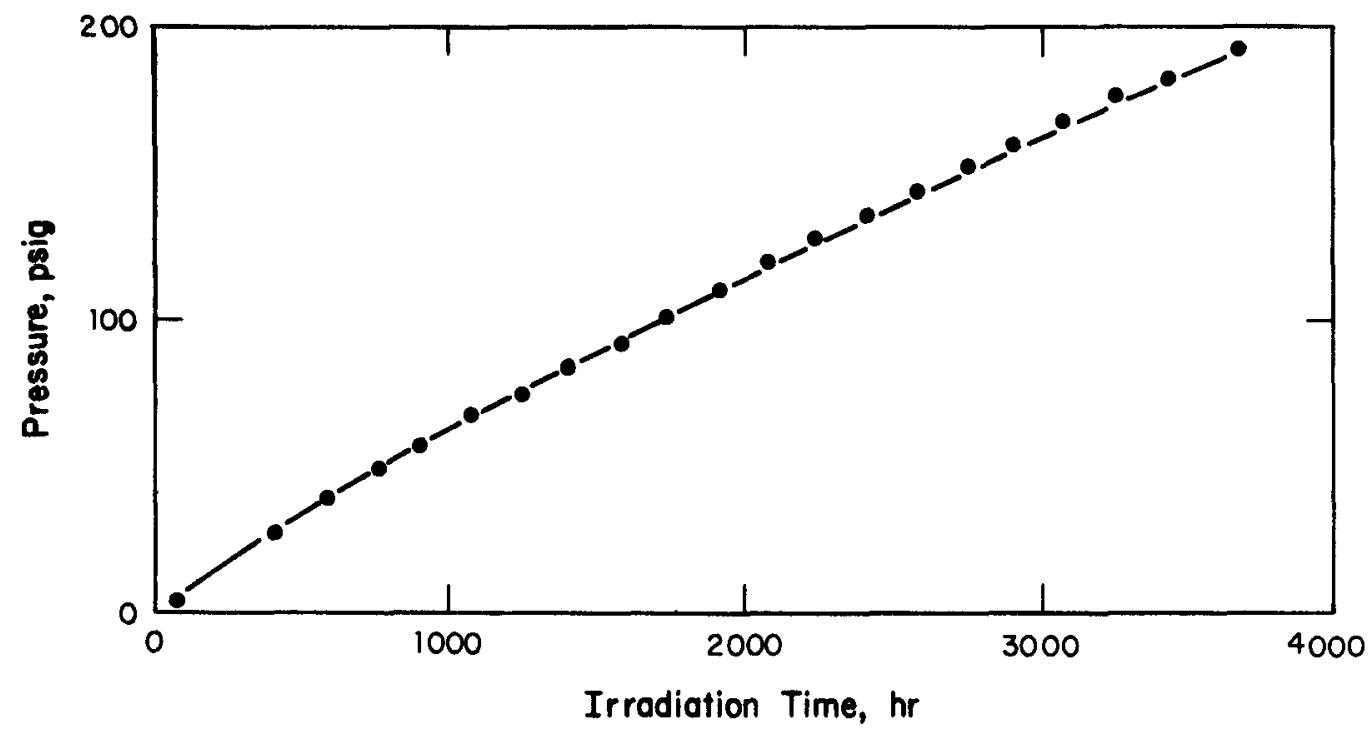

FIGURE 13. Pressure from Long-Term Alpha Radiolysis of Concrete Containing Fe-Mn Simulated SRP Waste 
RADIATION DOSES TO CONCRETE FROM SRP WASTE DURING LONG-TERM STORAGE

Principal sources of radiation in SRP waste in concrete waste forms for long-term storage will be the fission products ${ }^{90} \mathrm{Sr}$ and ${ }^{137} \mathrm{Cs}$ and the transuranic isotopes ${ }^{238} \mathrm{Pu}$ and ${ }^{2{ }^{39}} \mathrm{Pu} .{ }^{1}$ Based on data for the conceptual waste solidification process, initial dose rates to the forms will be $5.4 \times 10^{4} \mathrm{rads} / \mathrm{hr}$ for beta-gamma radiation and on $1 \mathrm{y} 300 \mathrm{rads} / \mathrm{hr}$ for alpha particles. As the isotopes decay, these dose rates decrease (Figure 14). After about 700 years when $>99 \%$ of the ${ }^{90} \mathrm{Sr},{ }^{13}{ }^{7} \mathrm{Cs}$, and ${ }^{238} \mathrm{Pu}$ have decayed, the dose rate is only about $7 \mathrm{rads} / \mathrm{hr}$, mainly due to $2{ }^{29} \mathrm{Pu}$. This dose rate corresponds to $630 \mathrm{nCi}$ of ${ }^{239} \mathrm{Pu} / \mathrm{g}$ of concrete waste form. Accumulated doses to the forms are shown in Figure 15. The final beta-gamma dose from ${ }^{90} \mathrm{Sr}$ and ${ }^{13}{ }^{7} \mathrm{Cs}$ is about 100 times larger than the alpha dose from ${ }^{238} \mathrm{Pu}$ and ${ }^{239} \mathrm{Pu}$.

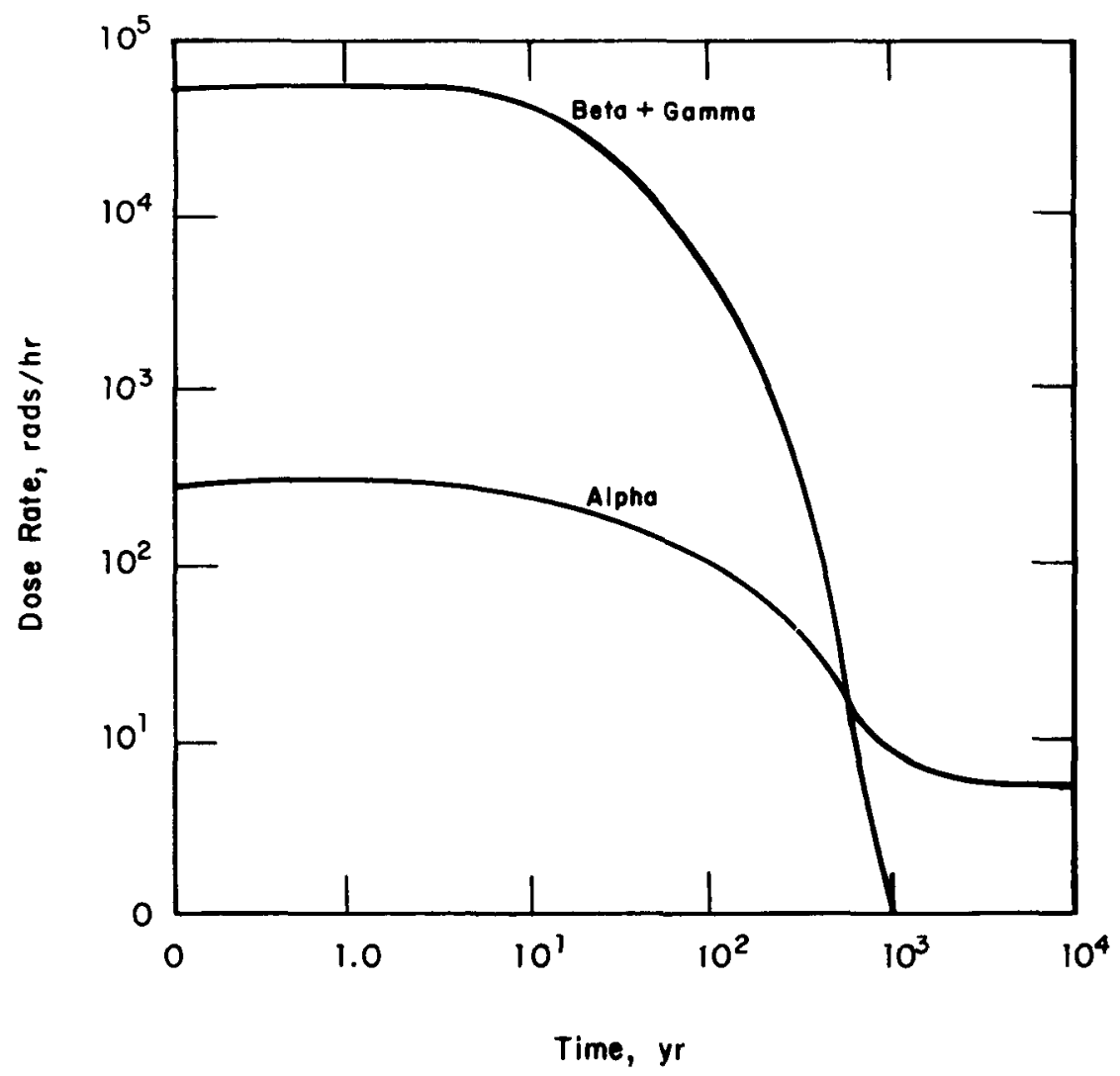

FIGURE 14. Calculated Dose Rates in Concrete Containing Radioactive SRP Waste 


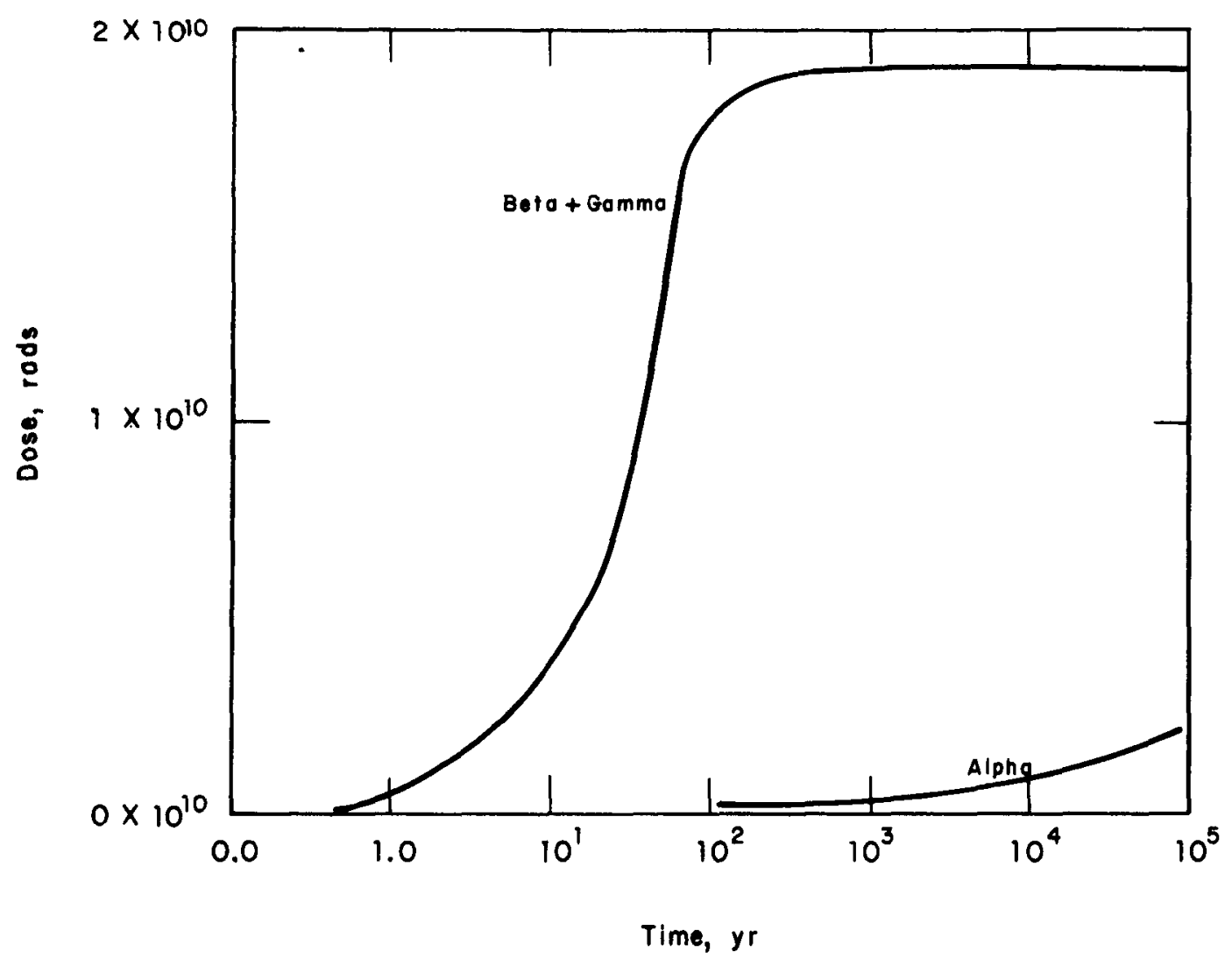

FIGURE 15. Calculated Doses in Concrete Containing Radioactive SRP Waste

Nuclear properties of the principal radioactive isotopes irradiating the concrete wastes are shown in Table $7 .{ }^{90} \mathrm{Sr}$ and ${ }^{137} \mathrm{Cs}$ are in secular equilibrium with their beta decay products ${ }^{90} \mathrm{Y}$ and ${ }^{137 \mathrm{~m}} \mathrm{Ba}$; thus, these isotopes irradiate the concrete at the same rate as their parent isotopes. All of the energy of the alpha and beta particles will be sorbed by the concrete because of the short ranges of these particles (about $0.004 \mathrm{~cm}$ ). The fraction of gamma ray energy absorbed can be estimated from the equation for energy transmitted from a cylinder by homogeneously distributed radiation sources. 16 
TABLE 7

Principal Isotopes Solidified in SRP Concrete Waste ${ }^{15}$

Isotope Half-Life $\frac{\text { Decay Heats, w/kilocurie }}{\text { Alpha Beta Gama }}$

$\begin{array}{llccc}{ }^{90} \mathrm{Sr} & 28 \mathrm{yr} & - & 1.18 & - \\ { }^{90} \mathrm{Y} & 64.2 \mathrm{hr} & - & 5.59 & - \\ { }^{137} \mathrm{Cs} & 26.6 \mathrm{yr} & - & 1.23 & - \\ { }^{137 \mathrm{~m}_{\mathrm{Ba}}} & 2.6 \mathrm{~m} & - & - & 3.61 \\ { }^{238} \mathrm{Pu} & 88 \mathrm{yr} & 32.5 & - & - \\ { }^{239} \mathrm{Pu} & 24,400 \mathrm{yr} & 31.0 & - & -\end{array}$

The concrete forms in the conceptual process are $10 \times 2-\mathrm{ft}-$ OD cylinders. The linear absorption coefficient for $137 \mathrm{~m} \mathrm{Ba}$ gamma rays $(E=0.66 \mathrm{MeV})$ in concrete is estimated to be $0.18 / \mathrm{cm} .^{19}$ With these values, about $9 \%$ of the gamma energy is transmitted; thus, about $91 \%$ is absorbed. In the conceptual process, $2 \times 10^{8}$ $\mathrm{Ci}$ of ${ }^{90} \mathrm{Sr}, 2 \times 10^{8} \mathrm{Ci}$ of ${ }^{137} \mathrm{Cs}, 4 \times 10^{5} \mathrm{Ci}$ of ${ }^{238} \mathrm{Pu}$, and $10^{4} \mathrm{Ci}$

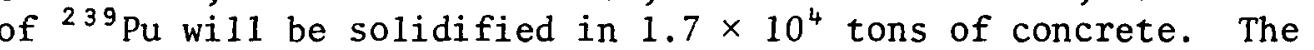
initial dose rate from a specific isotope is given by

$$
I_{0}=\frac{(\mathrm{Ci})_{0}(\mathrm{H})(\mathrm{K})}{M}
$$

where

$I_{0} \quad=$ the initial rate in rads $/ \mathrm{hr}$

$(\mathrm{Ci})_{0}=$ the curies of the isotope

$\mathrm{H} \quad=$ its decay heat in watts/Ci

$\mathrm{M}=$ the mass of concrete in $\mathrm{g}$

$\mathrm{K}=\mathrm{a}$ conversion factor, $2.8 \times 10^{-9}(\mathrm{rads} / \mathrm{hr}) /($ watt $/ \mathrm{g})$

Because of radioactive decay, the initial dose rate decreases according to the equation

$$
I=I_{0} e^{-\lambda t}
$$

where $\lambda$ is the decay constant $\left(0.693 / t_{\frac{1}{2}}\right)$ for the isotope being considered. Integration of this equation gives the dose $D$ as a function of time. 


$$
D=\frac{I_{0}}{\lambda}\left(1-e^{-\lambda t}\right)
$$

To calculate the results in Figures 14 and 15 , all of the gamma energy was assumed to be absorbed.

\section{MEASURED PRESSURIZATION IN CONTAINERS OF}

CONCRETE AND SRP WASTE

Samples of concrete containing actual SRP waste had been prepared for another program ${ }^{5}$ in which other properties of concrete as a waste solidification matrix were evaluated. To measure radiolytic pressurization, two of these samples were sealed in containers that had attached pressure gages. The pressure was monitored for about 1 year. Results (Figure 16) were completely consistent with those expected from low-dose rate gamma radiolysis of concrete containing simulated SRP waste. The pressure initially decreased to less than atmospheric and then increased. In one test, a steady-state pressure of 7 psi was achieved.

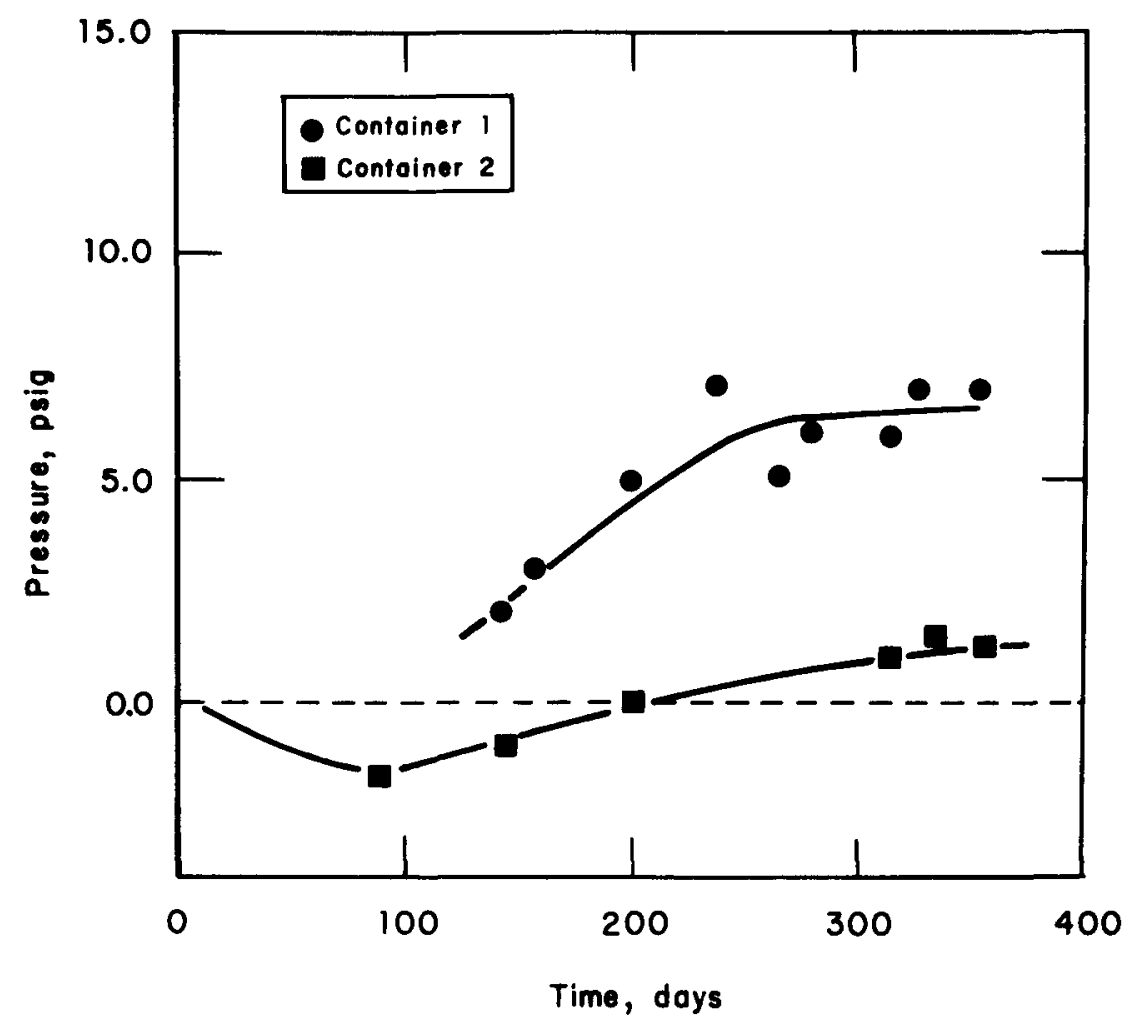

FIGURE 16. Pressure from Concrete Containing Radioactive SRP Waste 
The dose rate from the radioactive isotopes in these samples was calculated by methods described in the previous section. The result was $3 \times 10^{4} \mathrm{rads} / \mathrm{hr}$. At this dose rate, a steady-state pressure from 4 to $20 \mathrm{psi}$ is indicated by Figure 5 . The observed steady-state pressure of $7 \mathrm{psi}$ is within the 4 to $20 \mathrm{psi}$ range. This agreement supports the conclusion that steady-state pressures from gamma radiolysis of concrete containing simulated waste can be used to estimate steady-state pressures that will occur in containers of concrete and actual SRP waste.

As indicated in Figure 14, one of the gages indicated that initially the pressure decreased to less than atmospheric. Previous results indicated that this decrease in pressure was caused by $\mathrm{O}_{2}$ depletion. Although the other gage could not measure pressures less than atmospheric, evidence for such a decrease is indicated by extrapolation of the curve to zero time. Both containers had $165 \mathrm{~g}$ of concrete; therefore, the difference between pressurization rates in the two systems was due to differing void volumes in the containers and pressure gages. After about 1 year, both containers leaked, possibly because of radiation damage to a gasket below the pressure gage.

The two concrete samples contained $37.5 \mathrm{wt} \%$ of washed, dried wastes from SRP waste tank 15 . Also, 2.5 wt $\%{ }^{137} \mathrm{Cs}-$ loaded zeolite from removal of ${ }^{137} \mathrm{Cs}$ from the waste supernate was present. ${ }^{5}$ Major components of this waste are listed in Table 8. The ${ }^{137} \mathrm{Cs}$ content of the zeolite was $45 \mathrm{mCi} / \mathrm{g},{ }^{4}$ and the water-to-cement ratio of the concrete was $0.8 .^{5}$ The beta dose rate, calculated from the ${ }^{90} \mathrm{Sr},{ }^{144} \mathrm{Ce}$, and ${ }^{137} \mathrm{Cs}$ content was $3 \times 10^{4} \mathrm{rads} / \mathrm{hr}$. The alpha-dose rate was on $1 \mathrm{y} 0.04 \times 10^{4}$ $\mathrm{rads} / \mathrm{hr}$. The most significant alpha emitter was assumed to be ${ }^{238} \mathrm{Pu}$. The gamma-dose rate was negligible because of the small amount of ${ }^{139} \mathrm{Cs}$ present and the small size of the samples

$(1$ inch $O D \times 5$ inches tal1). 
TABLE 8

Major Components in Washed, Dried Tank 15 Waste $^{15}$

Chemical

Composition

Element Wt \%

$\frac{\text { Radionuclide Content }}{\text { Isotope }}$

A1

33.5

${ }^{90} \mathrm{Sr}$

25.6

$\mathrm{Fe}$

3.1

${ }^{144} \mathrm{Ce}$

16.9

Mn

2.3

${ }^{106} \mathrm{Ru}$

1.7

$\mathrm{Na}$

1.2

${ }^{125} \mathrm{Sb}$

1.3

$\mathrm{Hg}$

0.9

${ }^{154} \mathrm{Eu}$

1.2

$\mathrm{U}$

0.9

Gross Alpha

0.14

$\mathrm{NO}_{3}{ }^{-}$

5.0

$\mathrm{NO}_{2}{ }^{-}$

0.04

\section{CALCULATED PRESSURIZATION IN CONTAINERS OF CONCRETE AND SRP WASTE DURING LONG-TERM STORAGE}

To estimate the long-term pressurization in sealed containers of concrete and SRP waste, data from gamma and alpha radiolysis tests of concrete containing simulated wastes were used. The gases $\mathrm{H}_{2}, \mathrm{O}_{2}$, and $\mathrm{N}_{2} \mathrm{O}$ produced by radiolysis and $\mathrm{He}$ produced by neutralization of alpha particles were considered.

$\mathrm{H}_{2}$ and $\mathrm{O}_{2}$ Production

During the time period when the beta and gamma dose rate from ${ }^{90} \mathrm{Sr}$ and ${ }^{137} \mathrm{Cs}$ is larger than the alpha dose rate from ${ }^{2{ }^{9}} \mathrm{Pu}$ and ${ }^{238} \mathrm{Pu}$, the $\mathrm{H}_{2}$ pressure will be a steady-state value between 8 and $28 \mathrm{psi}$; the $\mathrm{O}_{2}$ pressure will decrease to almost zero. The range for the $\mathrm{H}_{2}$ pressure is based on extrapolation of data in Figure 6 to $5.4 \times 10^{4} \mathrm{rads} / \mathrm{hr}$, the combined beta-gamma dose rate calculated for the concrete. This time period is about 300 years. After ${ }^{90} \mathrm{Sr}$ and ${ }^{137} \mathrm{Cs}$ decay, ${ }^{238} \mathrm{Pu}$ and ${ }^{239} \mathrm{Pu}$ alpha radiolysis will become dominant; and the $\mathrm{H}_{2}$ and $\mathrm{O}_{2}$ pressures will increase. The $\mathrm{H}_{2}$ pressure will increase twice as fast as the $\mathrm{O}_{2}$. These increases will be nearly linear, to at least 200 psig, and are shown in the solid lines in Figure 17. If the increases continue linearly until the ${ }^{239} \mathrm{Pu}$ completely decays (in about $2 \times 10^{5}$ years). The final pressures in conceptual waste containers $(2 \times 10$ feet tall with $10 \%$ free volume) will be 1400 psi for $\mathrm{H}_{2}$ and $700 \mathrm{psi}$ for $\mathrm{O}_{2}$. These increases are shown in the dashed line in Figure 17. Estimates of pressures as a function of storage time are shown in Figure 17 . 


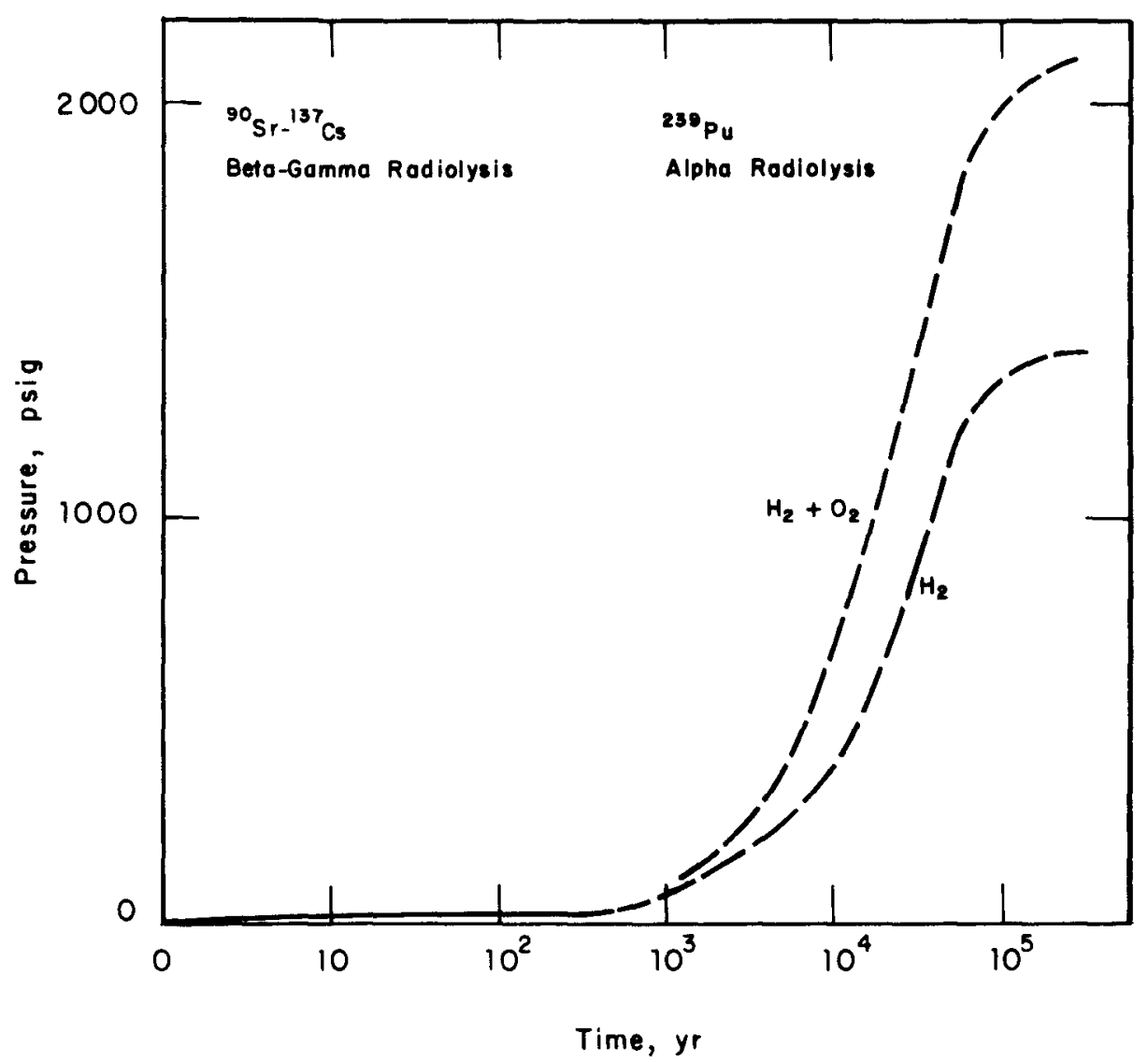

FIGURE 17. Estimate of Long-Term Pressurization from Concrete Containing Radioactive SRP Waste

Calculated from $\mathrm{G}\left(\mathrm{H}_{2}\right)=0.21$ molecules $/ 100 \mathrm{eV}$ and $G\left(\mathrm{O}_{2}\right)=0.1$ molecules $/ 100 \mathrm{eV}$ for alpha radiolysis

---- Calculated, assuming $\mathrm{G}\left(\mathrm{H}_{2}\right)$ and $\mathrm{G}\left(\mathrm{O}_{2}\right)$ for alpha radiolysis independent of $\mathrm{H}_{2}$ or $\mathrm{O}_{2}$ pressure

The $\mathrm{H}_{2}$ and $\mathrm{O}_{2}$ pressures in the containers from alpha radiolysis were calculated by using the ideal gas law, the alpha radiolysis dose, and the value for the number of molecules of $\mathrm{H}_{2}$ or $\mathrm{O}_{2}$ produced per unit energy absorbed by the concrete. This latter quantity in terms of $100 \mathrm{eV}$ of energy absorbed is termed the G-value and was calculated from data in Table 6 and Figures 12 and 13 by using the equation 


$$
G=\frac{\text { FST:100 }}{\text { RTI }}
$$

Here,

$F=$ fraction of evolved gas that is $\mathrm{H}_{2}$ or $\mathrm{O}_{2}$

$S=$ total rate of pressure increase (slopes in Figure 12) (psi/hr)

$V=$ gas volume $(\mathrm{mL})$

$\mathrm{R}=$ gas constant $(1205 \mathrm{psi} \mathrm{mL} / \mathrm{mole} \mathrm{K})$

$\mathrm{T}=$ temperature $(296 \mathrm{~K})$

$\mathrm{N}=$ number $\left(6.02 \times 10^{23} \mathrm{molecules} / \mathrm{mole}\right)$

$\mathrm{I}=\operatorname{dose} \operatorname{rate}(\mathrm{eV} / \mathrm{hr})$

For the four alpha radiolysis tests, $\mathrm{G}\left(\mathrm{H}_{2}\right)$ was $0.21 \pm 0.01$ molecules/100 eV. $\mathrm{G}\left(\mathrm{O}_{2}\right)$ was 0.1 molecules $/ 100 \mathrm{eV}$ from the long-term radiolysis data in Figure 13. Pressure in the container at any time was calculated from

$$
P_{t}=\frac{G(X) R^{\prime} T K^{\prime} D}{100 N V}
$$

In this case,

$\mathrm{V}=$ gas volume in a container $(\mathrm{mL})$

$M=$ mass of cement in a canister $(\mathrm{g})$

$\mathrm{K}^{\prime}=$ conversion factor $6.24 \times 10^{13} \mathrm{eV} / \mathrm{g} \mathrm{rad}$

$D=$ alpha dose at time $t$ from ${ }^{239} \mathrm{Pu}$

The container was assumed to be a 2-foot-ID cylinder, 10 feet tall and to hold 1.5 tons of concrete waste. A $10 \%$ free volume was assumed, and the concrete was assumed to have $10 \%$ porosity. The dose $\mathrm{D}$ was calculated from Equation 3 with $\mathrm{I}_{\mathrm{O}}$ equal to the initial dose rate due to ${ }^{239} \mathrm{Pu}(7 \mathrm{rads} / \mathrm{hr})$. Alpha radiation from ${ }^{238} \mathrm{Pu}$ remaining after decay of the ${ }^{90} \mathrm{Sr}$ and ${ }^{13}{ }^{7} \mathrm{Cs}$ (in 300 years) contributes on $1 y 0.6 \%$ of the total dose from ${ }^{2}{ }^{9} \mathrm{Pu}$ and was thus neglected. For this calculation, the rate of pressurization was assumed to be independent of $\mathrm{H}_{2}$ pressures up to $1400 \mathrm{psi}$ and independent of $\mathrm{O}_{2}$ pressures up to $700 \mathrm{psi}$. In the experiments with simulated wastes, pressurization rate was tested to only 200 psig because of hazards associated with working 
with high pressures in radioactive-containment glove boxes. Further experiments would be necessary to determine if the pressurization rate was affected by higher $\mathrm{H}_{2}$ and $\mathrm{O}_{2}$ pressures.

\section{$\mathrm{N}_{2} \mathrm{O}$ Production}

The possibility of $\mathrm{N}_{2} \mathrm{O}$ production in the containers must also be considered even though it was not produced in all the radiolysis tests. It was detected only in the gamma radiolysis of concrete containing $\mathrm{Fe}-\mathrm{Mn}$ simulated waste or containing reagent-grade $\mathrm{Fe}_{2} \mathrm{O}_{3}$ and $\mathrm{NO}_{3}{ }^{-}$or $\mathrm{NO}_{2}{ }^{-}$ions. If these ions are present in the SRP waste, $\mathrm{N}_{2} \mathrm{O}$ may be produced in the storage containers. However, it will probably not reach appreciable pressures because, as indicated by the gamma radiolysis tests where $\mathrm{NO}_{3}{ }^{-}$and $\mathrm{NO}_{2}{ }^{-}$were added and also by the tests with simulated sludge, the $\mathrm{H}_{2}$ generated can stop $\mathrm{N}_{2} \mathrm{O}$ pressurization. Also, $\mathrm{N}_{2} \mathrm{O}$ production can be reduced by washing sorbed $\mathrm{NO}_{3}{ }^{-}$and $\mathrm{NO}_{2}{ }^{-}$ions from the waste. If no effect of $\mathrm{H}_{2}$ on $\mathrm{N}_{2} \mathrm{O}$ production is assumed, the estimated maximum $\mathrm{N}_{2} \mathrm{O}$ pressure in the actual canisters is $<60$ psi based on the measured $\mathrm{NO}_{3}{ }^{-}$and $\mathrm{NO}_{2}{ }^{-}$content of the actual wastes. ${ }^{14}$

The maximum $\mathrm{N}_{2} \mathrm{O}$ pressure was calculated with Equation 5 by assuming that $\mathrm{N}_{2} \mathrm{O}$ production was linear with dose. In this calculation, $D$ was the total beta-gamma dose from decay of ${ }^{90} \mathrm{Sr}$ and $\left.{ }^{13}{ }^{7} \mathrm{Cs} . \mathrm{G}_{2} \mathrm{O}\right)$ was calculated with data from the radiolysis at $8.9 \times 10^{4} \mathrm{rads} / \mathrm{hr}$ of concrete containing $\mathrm{Fe}_{2} \mathrm{O}_{3}$ with added $\mathrm{NO}_{3}{ }^{-}$and $\mathrm{NO}_{2}{ }^{-}$ions (see Table 3 and Figure 7 ). The equation for calculating $\mathrm{G}\left(\mathrm{N}_{2} \mathrm{O}\right)$ is

$$
G\left(\mathrm{~N}_{2} \mathrm{O}\right)=\frac{\mathrm{F}_{\mathrm{N}_{2} \mathrm{O}} \mathrm{P}^{\mathrm{VN} 100}}{\mathrm{RTK}^{\prime} \mathrm{MD}_{\mathrm{f}}}
$$

where

$\mathrm{F}=$ fraction of the gas that is $\mathrm{N}_{2} \mathrm{O}$

$P_{f}=$ final pressure of the gas

$M=$ mass of concrete (including $\mathrm{H}_{2} \mathrm{O}$ ) that was irradiated

$D_{f}=$ dose in rads at the end of radiolysis

For the test with $5 \% \mathrm{NO}_{3}{ }^{-}$present (see Table 5 and Figure 7), $\mathrm{G}\left(\mathrm{N}_{2} \mathrm{O}\right)$ was 0.001 molecules $/ 100 \mathrm{eV}$. With the final calculated beta-gamma dose of $1.9 \times 10^{10}$ rads for $D$ in Equation 5 , a final 
pressure of $60 \mathrm{psi}$ is calculated. When $2.5 \mathrm{wt} \% \mathrm{NO}_{2}{ }^{-}$was present, $\mathrm{G}\left(\mathrm{N}_{2} \mathrm{O}\right)$ increased significantly to 0.008 molecules $/ 100 \mathrm{eV}$. In this case, the final calculated $\mathrm{N}_{2} \mathrm{O}$ pressure would be about $400 \mathrm{psi}$. However, the actual $\mathrm{NO}_{2}{ }^{-}$content of the waste is much lower; thus, much lower pressures would be predicted. Measured values for $\mathrm{NO}_{2}{ }^{-}$are 0.03 to $0.09 \mathrm{wt} \%$; and for $\mathrm{NO}_{3}{ }^{-}$, measured values are 0.5 to $5 \mathrm{wt} \%{ }^{17}$ Based on these values and the measured effect of $\mathrm{NO}_{2}{ }^{-}$on $\mathrm{N}_{2} \mathrm{O}$ production (lowering the $\mathrm{N}_{2} \mathrm{O}$ content by a factor of 5 lowered the $\mathrm{N}_{2} \mathrm{O}$ production rate by a factor of 2.5), a maximum pressure of about $60 \mathrm{psi}$ is predicted. This pressure would occur in a container containing concrete and waste that is 5 wt $\% \mathrm{NO}_{3}{ }^{-}$and $<0.2 \% \mathrm{NO}_{2}{ }^{-}$. Lower pressures would be generated with waste of lower $\mathrm{NO}_{3}{ }^{-}$and $\mathrm{NO}_{2}{ }^{-}$content.

He Production

Helium will also form in the containers from neutralization of alpha particles from ${ }^{238} \mathrm{Pu}$ and ${ }^{239} \mathrm{Pu}$. Because the amounts of these isotopes are sma11, the He pressure after decay of the $238,239 \mathrm{Pu}$ will only be $0.2 \mathrm{psi}$ and thus negligible.

Helium pressurization in a canister was calculated from the initial ${ }^{238} \mathrm{Pu}$ and ${ }^{239} \mathrm{Pu}$ content $\left(29 \mathrm{Ci}\right.$ for ${ }^{238} \mathrm{Pu}$ and $1 \mathrm{Ci}$ for $\left.{ }^{239} \mathrm{Pu}\right)$ and the ideal gas $1 \mathrm{aw}$.

\section{MECHANISM FOR RADIOLYTIC GAS PRODUCTION}

Almost all the data from this study are consistent with the free radical mechanism for radiolytic decomposition of water developed from many studies on the radiolysis of liquid water. ${ }^{18}$ This mechanism can qualitatively explain $\mathrm{H}_{2}$ production and $\mathrm{O}_{2}$ consumption; attainment of an equilibrium pressure and its dose rate dependence, the effect of added $\mathrm{NO}_{3}{ }^{-}$ions or organic set retarders, and the differences between gamma and alpha radiolysis.

In this mechanism, the radiation interacts with water in concrete and produces $\mathrm{H}$ atoms and $\mathrm{OH}$ radicals by excitation and dissociation or by ionization followed by neutralization. These reactions are

$$
\begin{aligned}
& \mathrm{H}_{2} \mathrm{O} \rightarrow \mathrm{H}_{2} \mathrm{O}^{*} \rightarrow \mathrm{H}+\mathrm{OH} \\
& \mathrm{H}_{2} \mathrm{O} \rightarrow \mathrm{H}_{2} \mathrm{O}^{+}+\mathrm{e}^{-} \\
& \mathrm{H}_{2} \mathrm{O}^{+}+\mathrm{H}_{2} \mathrm{O} \rightarrow \mathrm{H}_{3} \mathrm{O}^{+}+\mathrm{OH} \\
& \mathrm{H}_{3} \mathrm{O}^{+}+\mathrm{e}^{-} \rightarrow \mathrm{H}_{2} \mathrm{O}+\mathrm{H}
\end{aligned}
$$


There is no reason to assume that these reactions cannot occur when the water molecules are incorporated into concrete, a rigid metal oxide framework. Once formed, the $\mathrm{H}$ atoms and $\mathrm{OH}$ radicals can migrate until they react with other radicals to form $\mathrm{H}_{2}$ and $\mathrm{H}_{2} \mathrm{O}_{2}$, or water.

$$
\begin{aligned}
& \mathrm{H}+\mathrm{H} \rightarrow \mathrm{H}_{2} \\
& \mathrm{OH}+\mathrm{OH} \rightarrow \mathrm{H}_{2} \mathrm{O}_{2} \\
& \mathrm{H}+\mathrm{OH} \rightarrow \mathrm{H}_{2} \mathrm{O}
\end{aligned}
$$

Production of $\mathrm{H}_{2} \mathrm{O}_{2}$ by radiolysis was indicated by positive tests obtained from treating irradiated samples of neat cement and of concrete containing $\mathrm{Fe}_{2} \mathrm{O}_{3}$ or $\mathrm{Fe}-\mathrm{Al}$ waste with reagents sensitive to $\mathrm{H}_{2} \mathrm{O}_{2} .{ }^{19}$ These reagents were a neutral solution of $\mathrm{Fe}(\mathrm{Cl})_{3}-\mathrm{Fe}(\mathrm{CN})_{4}^{-}$and an acidic solution of $\mathrm{KI}$ containing stabilized starch.

The $\mathrm{H}$ and $\mathrm{OH}$ radicals are also capable of reactions with sorbed stable molecules or ions.

$$
\begin{aligned}
& \mathrm{OH}+\mathrm{H}_{2} \rightarrow \mathrm{H}_{2} \mathrm{O}+\mathrm{H} \\
& \mathrm{OH}+\mathrm{H}_{2} \mathrm{O}_{2} \rightarrow \mathrm{H}_{2} \mathrm{O}+\mathrm{HO}_{2} \\
& \mathrm{H}+\mathrm{H}_{2} \mathrm{O}_{2} \rightarrow \mathrm{H}_{2} \mathrm{O}+\mathrm{OH} \\
& \mathrm{H}+\mathrm{O}_{2} \rightarrow \mathrm{HO}_{2} \\
& \mathrm{H}+\mathrm{NO}_{3}^{-} \rightarrow \mathrm{OH}^{-}+\mathrm{NO}_{2}
\end{aligned}
$$

Reaction 5 accounts for $\mathrm{H}_{2}$ production, and Reaction 11 accounts for $\mathrm{O}_{2}$ consumption. The $\mathrm{HO}_{2}$ radicals react as follows:

$$
\mathrm{HO}_{2}+\mathrm{HO}_{2} \rightarrow \mathrm{H}_{2} \mathrm{O}_{2}+\mathrm{O}_{2}
$$

Reaction 12 accounts for $\mathrm{NO}_{3}^{-}$lowering the rate of $\mathrm{H}_{2}$ production. Reaction 8 accounts for the steady-state $\mathrm{H}_{2}$ pressures. Once the $\mathrm{H}_{2}$ pressure is such that the rates of 5 and 8 are equal, steady-state equilibrium is attained.

An experiment was performed to test the hypothesis that Reaction 8 is significant in affecting the steady state. A concrete containing $7 \mathrm{wt} \% \mathrm{Br}^{-}$was prepared by adding $\mathrm{NaBr}$ solution to the cement. This sample and one not containing $\mathrm{Br}^{-}$were irradiated at $1.4 \times 10^{7} \mathrm{rads} / \mathrm{hr}$ in a ${ }^{60} \mathrm{Co}$ source. Bromide was added to scavenge $\mathrm{OH}$ radicals.

$$
\mathrm{OH}+\mathrm{Br}^{-} \rightarrow \mathrm{Br}+\mathrm{OH}^{-}
$$


This reaction lowers the rate of Reaction 8 and thus, steady state should not be achieved when $\mathrm{Br}^{-}$ions were present. As shown in Figure 18, steady state was not achieved, indicating that Reaction 8 is significant in causing the steady state. At the end of the tests, gas compositions were $79 \% \mathrm{H}_{2}, 16 \% \mathrm{O}_{2}$, and $6 \% \mathrm{~N}$ in the presence of $\mathrm{Br}^{-}$and $83 \% \mathrm{H}_{2}, 2 \% \mathrm{O}_{2}$, and $16 \% \mathrm{~N}_{2}$ in its absence. In the presence of $\mathrm{Br}^{-}, \mathrm{O}_{2}$ was a product; in the absence of $\mathrm{Br}^{-}, \mathrm{O}_{2}$ was depleted. $\mathrm{O}_{2}$ resulted from reduction of $\mathrm{Br}$ by $\mathrm{HO}_{2}$ or $\mathrm{H}_{2} \mathrm{O}_{2}$.

$$
\begin{aligned}
& \mathrm{HO}_{2}+\mathrm{Br} \rightarrow \mathrm{HBr}+\mathrm{O}_{2} \\
& \mathrm{H}_{2} \mathrm{O}_{2}+2 \mathrm{Br} \rightarrow 2 \mathrm{HBr}+\mathrm{O}_{2}
\end{aligned}
$$

Reactions 9 through 12 also affect the steady-state pressure but not as significantly as Reaction 8 . The dose-rate effect on the steady-state pressure (Figure 4) results from the dose-rate effect on Reactions 5 and 8 . As the dose rate increases, the rates of both reactions increase; however, Reaction 5 increases faster because it is second order with respect to the radical concentration, and Reaction 8 is first order. ${ }^{20}$ To compensate for the faster increase of Reaction 5, higher $\mathrm{H}_{2}$ concentrations (or pressures) are necessary.

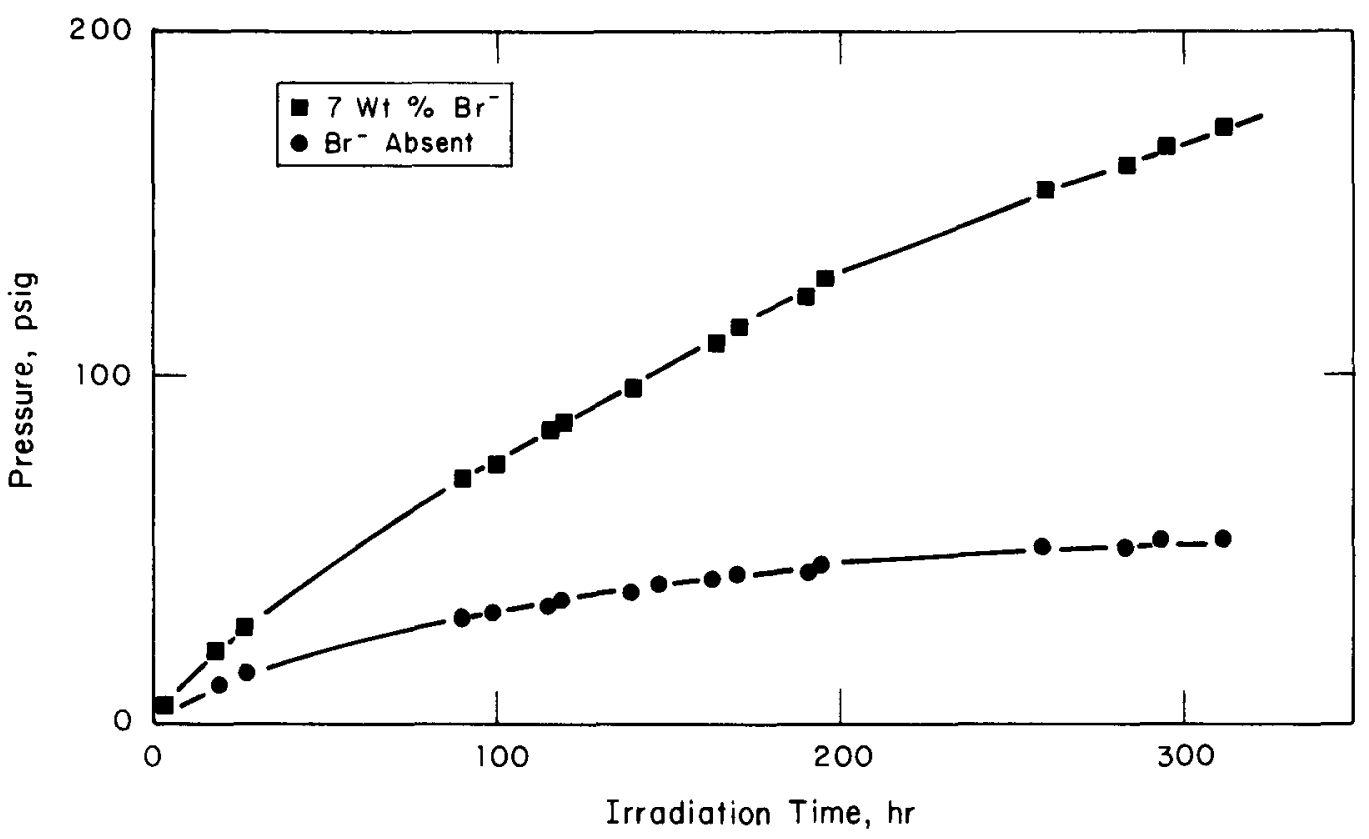

FIGURE 18. Effect of Bromide Ions on Pressurization from Gamma Radiolysis of Concrete 
Reaction 11 accounts for $\mathrm{O}_{2}$ depletion. This reaction may also occur with organic radicals produced when an organic set retarder is present. Reaction 12 accounts for the lowering of $\mathrm{H}_{2}$ production by $\mathrm{NO}_{3}{ }^{-}$ions. The $\mathrm{NO}_{2}$ could eventually be reduced to $\mathrm{NO}_{2}{ }^{-}$or be reoxidized by $\mathrm{OH}$ to $\mathrm{HNO}_{3}$. An explanation of the failure of steady state to be achieved at high-dose rates when $\mathrm{NO}_{3}{ }^{-}$ions were present is not immediately apparent.

When an organic set retarder is present, $\mathrm{H}_{2}$ may be formed in a one-step process by radiolysis of the organic molecule. ${ }^{21}$ Also, the organic radical cannot react with $\mathrm{H}_{2} ;^{21}$ thus, steady state is not achieved by pressurizing the system with $\mathrm{H}_{2}$. However, no immediate explanation of why steady state was achieved at high-dose rates is evident (Figure 12). Perhaps a secondary product formed by the large doses in this test caused steady state.

Differences between alpha and gamma radiolysis result from differences in the spatial distribution of the $\mathrm{H}$ and $\mathrm{OH}$ radicals formed by the two types of radiation. Alpha particles lose energy in a much smaller volume than gamma rays; thus, the intermediates are formed much closer together. The efficiencies of Reactions 5, 6, and 7 are therefore increased. Reaction 8 cannot compete sufficiently to cause steady state. Oxygen may result from the reaction of $\mathrm{OH}$ with $\mathrm{H}_{2} \mathrm{O}_{2}$ accumulated in the concrete (Reaction 9). $\mathrm{O}_{2}$ would then recombine with the $\mathrm{HO}_{2}$ radicals, and the probability of Reaction 8 would decrease if $\mathrm{OH}$ radicals were removed. 


\section{REFERENCES}

1. R. M. Wallace, H. L. Hull, and R. F. Bradley. Solid Forms for Savannah River Plant High-Level Waste. USAEC Report DP-1335, Savannah River Laboratory, E. I. du Pont de Nemours and Company, Aiken, SC (1973).

2. G. H. Thompson. Evaluation of Mineralization Processes for SRP Waste. USERDA Report DP-1389, Savannah River Laboratory, E. I. du Pont de Nemours and Company, Aiken, SC (1975).

3. J. R. Wiley and R. M. Wallace. Removal of Cesium from Savannah River Plant Waste Supernate. USERDA Report DP-1388, Savannah River Laboratory, E. I. du Pont de Nemours and Company, Aiken, SC (1975).

4. J. R. Wiley. Decontomination of Savannah River Plant Waste Supermate. USERDA Report DP-1436, Savannah River Laboratory, E. I. du Pont de Nemours and Company, Aiken, SC (1976).

5. J. A. Stone. Separation of SRP Waste Sludge and Supermate. USERDA Report DP-1441, Savannah River Laboratory, E. I. du Pont de Nemours and Company, Aiken, SC (1976).

6. J. A. Kelley. Evaluation of Glass as a Matrix for Solidification of Savannah River Plant Waste: Nonradioactive and Tracer Studies. USERDA Report DP-1382, Savannah River Laboratory, E. I. du Pont de Nemours and Company, Aiken, SC (1975).

7. J. A. Kelley. Evaluation of Glass as a Matrix for Solidification of Savannah River Plant Waste Radioactive Studies. USERDA Report DP-1397, Savannah River Laboratory, E. I. du Pont de Nemours and Company, Aiken, SC (1975).

8. J. A. Kelley and N. E. Bibler. Effects of Internal Alpha Radiation on Borosilicate Glass Containing Savannah River Plant Waste. DOE Report DP-1482, Savannah River Laboratory, E. I. du Pont de Nemours and Company, Aiken, SC (to be published).

9. M. L. Hyder. "The Radiolysis of Aqueous Nitrate Solutions." J. Phys. Chem. 69 (1965). 
10. J. A. Stone and P. D. d'Entremont. Measurement and Control of Cement Set Times in Waste Solidification. USERDA Report DP-1404, Savannah River Laboratory, E. I. du Pont de Nemours and Company, Aiken, SC (1976).

11. H. Fricke and E. J. Hart. Radiation Dosimetry, Vol. 2 (2nd Edition), p 185. F. H. Attix and W. C. Roesch, editors. Academic Press, New York, NY (1969).

12. N. E. Bibler. Calibration of Intense ${ }^{6} \mathrm{Co}$ Gamma Ray Sources at the Savannah River Plant. USERDA Report DP-1414, Savannah River Laboratory, E. I. du Pont de Nemours and Company, Aiken, SC (1976).

13. N. E. Bibler and E. G. Orebaugh. Radiolytic Gas Production from Tritiated Waste Forms, $\gamma$ - and $\alpha$-Radiolysis Studies. USERDA Report DP-1459, Savannah River Laboratory, E. I. du Pont de Nemours and Company, Aiken, SC (1977).

14. J. A. Stone, J. A. Kelley, and T. S. McMillan. Sampling and Analyses of SRP High-Level Waste Sludges. USERDA Report DP-1399, Savannah River Laboratory, E. I. du Pont de Nemours and Company, Aiken, SC (1976).

15. E. D. Arnold. Handbook of Shielding Requirements and Radiation Characteristics of Isotopic Power Sources for Terrestrial, Marine, and Space Applications. USAEC Report ORNL-3576, Oak Ridge National Laboratory, Oak Ridge, TN (1964).

16. B. T. Price and K. F. Spinney. Radiation Shielding. p 228, Pergamon Press, New York, NY (1957).

17. C. W. J. Wende. The Computation of Radiation Hazards. AECD Report 3661, E. I. du Pont de Nemours and Company, Wilmington, DE (1944).

18. I. G. Dragnic' and 2. D. Draganic'. The Radiation Chemistry of Water. Academic Press, New York, NY (1971).

19. F. Feigl. Spot Tests in Inorganic Analysis. p 354, Elsevier Publishing Company, New York, NY (1958).

20. W. G. Burns and R. Barker. "Dose Rate and Linear Energy Transfer Effects in Radiation Chemistry." Progress in Reaction Kinetics, 3, 305 (1965).

21. J. W. T. Spinks and R. J. Woods. An Introduction to Radiation Chemistry. p 309, John Wiley and Sons, Inc., New York, NY (1964). 